\title{
KUIDAS LÄTI-EESTI KEELEKONTAKT ON MÕJUTANUD EESTI MURDEKEELE GRAMMATIKAT JA SÕNAMOODUSTUST
}

\section{LEMBIT VABA}

Annotatsioon. Sissejuhatavalt käsitletakse artiklis balti-läänemeresoome keelekontakti üldisemalt. Läänemeresoome keelte sõnavara iseloomustab tüse balti laenukihistus, mis ulatub paarisaja, mõne uurija arvates koguni kuni poole tuhande laentüveni. Balti konta"kt on toonud läänemeresoome keeltesse peale leksikaalsete laenude fonotaktilisi ja morfosüntaktilisi uuendusi. Läti-eesti ja eesti-läti kontaktid on olnud keeleülesed, need on toimunud ja toimuvad prevaleerivate keelte vahendusel. Nii eesti kui ka läti keelt on mõjutanud ja mõjutavad kolm jõulist kontaktkeelt: saksa, vene ja inglise keel. Seetõttu on eesti ja läti keele vastastikuse morfoloogilise, süntaktilise ja semantilise mõju väljaselgitamine äärmiselt komplitseeritud. Artiklis käsitletakse eesti-läti keelepiiri kujunemist ja eesti keelesaarte teket Lätis ning läti-eesti keelekontakti iseloomu.

Artiklis analüüsitakse järgmisi võimalikke läti laene eesti murdekeele grammatikas: grammatilist sugu ja sootunnuseid puudutavaid ilminguid, plurale tantum-sõnu, superlatiivsuse lätipärast väljendamist, läti mõju kõneviiside moodustamisel (konditsionaal, debitiiv, optatiiv), verbitarindi finiitverb + sama verbi teonimi tõhususreduplikatsiooni, lätipäraseid verbirektsioone, läti mõju pronoomeni- ja adpositsioonisüsteemis, lätilaenulisi verbiprefikseid, partikleid, adverbe ja proadverbe Leivu murrakus ja Lutsi murdes ning lätilaenulisi konjunktsioone ja interjektsioone. Samuti vaadeldakse läti keele mõju sõnamoodustusele.

Võtmesõnad: läänemeresoome keeled, eesti keel, balti keeled, läti keel, keelekontaktid

\section{Sissejuhatavaid märkmeid}

Balti-läänemeresoome keelekontakti tuleb pidada katkematuks protsessiks. Läänemeresoome keelte sõnavara iseloomustab tüse balti laenukihistus, mis ulatub paarisaja, mõne uurija arvates koguni kuni poole tuhande laentüveni. Läänemeresoome keelte balti sõnalaenude ning liivi ja eesti keeles esinevate läti sõnalaenude vahel paikneb eelläti laenukihistis, mille selgeks 
näiteks peab artikli autor (peamiselt) kagueestilise levikuga eelläti laene struktuuriga $k$ - + eesvokaal. Sellise häälikehitusega laenud osutavad, et eesvokaalieelne velaarklusiil $k$ - või $g$ - polnud veel muutunud afrikaadiks (laenutüüp keris, käblik 'ahjulind' või kõno 'metsamesiniku nöörredel, ronimisnöör'; nende ja muude teemaga seotud sõnade etümoloogiat vt Vaba 1990: 35-45; 1992: 459-462; 1996: 33-35). Kirjeldatud positsioonis hõlmab afrikaadistumine aga kõiki tänapäeva läti keeleks sulanud lähedasi hõimukeeli (latgali, seeli, kurši).

Eesti alal kõneldud murrete häälikehituses ja grammatikas toimusid teise aastatuhande alguspoolel pKr ja sellele järgnenud sajandeil murrangulised muutused, sh sise- ja lõpukadu, järgsilpide pikkade vokaalide lühenemine, possessiivsufiksite kadu, ga-lõpulise komitatiivi teke, eitusverbi asendumine eitussõnaga, kaudse kõneviisi teke, pöördelõppude taandumine imperatiivist, pöördelõppude ärajätmine tingivas kõneviisis (Rätsep 1989: 1510 jj). Huno Rätsep küsib, kas ja kuivõrd mõjustas uuendisarja teket Skandinaavia viikingite (muinaspõhja) või alamsaksa keel või oli tegemist siiski keele enese häälikehituse sisemise arenguga (ibid.: 1515). Rätsep (ibid.: 1521) kaldub arvama, et keelemurrangu lähtekeskus paiknes Iõunaeesti murdealal. Kui arutluse all on eesti keele kõnealuse ajajärgu arengut suunanud välistegurite mõju, ei saa vaatlusest kõrvale jätta latgali hõime, kes hiljemalt 13. sajandi alguseks olid nihkunud lõunaeestlaste ja liivlaste vahetusse naabrusse või koguni asualadele. On oluline rõhutada, et balti hõimukeeled, millest kujunes tulevane läti keel, tegid samuti läbi rea hääliku- ja grammatikasüsteemi murrangulisi muutusi, samal ajal kui leedu ja muinaspreisi keel püsisid konservatiivsena.

Balti-läänemeresoome ja läänemeresoome-balti keelekontaktide iseloomu ja ulatuse kirjeldamisel on rõhutatud asümmeetriat: vanapreisi keeles pole üldse ja leedu keeles on vähe läänemeresoome sõnatüvesid, kusjuures need on enamasti lokaalse iseloomuga, piirdudes peamiselt Žemaitijas kõneldava murdekeelega, ja võivad vähemalt osaliselt olla hoopis hiline kuršipärasus. Läänemeresoome keelte, peamiselt liivi ja lõunaeesti keele mõju tuleb esile eelkõige läti keeles. Silmatorkava asümeetria seletuseks on Vilhelm Thomsenist peale pakutud läänemeresoomlastega kontaktis olnud põhjabaltlaste sulandumist läänemeresoomlastesse. Varasel kontaktiajastul vastastikku laenatud grammatilisi ja derivatsioonimorfeeme pole senine uurimistöö eriti esile toonud. Balti ja läänemeresoome keelte sarnasus ilmneb grammatiliste mallide ja nende funktsioonide 
sarnasuses. On avaldatud arvamust, et soome-ugri keelte mõju on balti ja slaavi keeltele olnud eelkõige konserveeriv (nn Kühlschrankeffekt).

Öeldu taustal on eriti huvipakkuv tõik, et leedu ja läti keele arhailisemas kihistises on esinenud soome-ugri tüüpi kohakäänete vasted, nimelt illatiiv, allatiiv, inessiiv ja adessiiv, mis on võimaldanud käändevormide abil väljendada siht- ja asukohta, kuid mitte lähtekohta, sest puudusid elatiiv ja ablatiiv. Seega moodustus vanaleedu käändesüsteem leedu keeleajaloolase Zigmas Zinkevičiuse (1984: 313 jj) järgi kümnest käändest. Kirjeldatud süsteem on taandunud nüüdisbalti keeltest, sest see polnud - baltoloogide arvates - piisavalt are kohasuhete kirjeldamiseks, mistõttu see korvati indoeuroopa keeltele iseloomulike eessõnafraasidega. Ainus erand on inessiiv, millest tänapäeva balti keeltes on arenenud uus lokatiiv. Muude indoeuroopa keeltega võrreldes on leedu ja läti keeles veel tänapäevalgi suhteliselt palju käändevorme: nominatiiv, genitiiv, daativ, akusatiiv, instrumentaal, lokatiiv ja vokatiiv (kokku seitse käänet). Zinkevičiuse (1982: 21 jj) järgi on postpositsioonilised kohakäänded kujunenud pikema aja jooksul, esmalt ainsuse-, hiljem mitmusevormid, sealjuures deklinatsioonitüübiti eri ajal. Ainsuslikud kohakäänded ning mitmuse illatiiv ja allatiiv kujunesid idabalti algkeele perioodil, postpositsiooniliste adessiivi ja inessiivi kujunemist mitmuses pärssis aga vana, $s u$-lõpuga indoeuroopa lokatiivi püsimine. Tagasõnad liitusid lokatiivile, akusatiivile või genitiivile kui enkliitikonid. Tagasõna $p i<$ pie enkliitiline iseloom on säilinud tänaseni. Postpositsiooniliste käänete vanapäraseid vorme leedu ja läti vanas kirjakeeles ning adverbides on nt ld galvon 'pähe', 1t kristan sists 'ristilöödud' ja mājup 'koju'.

Tabel 1. Balti kohakäänded (vanaleedu keele näitel): rank 'a 'käsi'

\begin{tabular}{|c|c|c|}
\hline Kaasus & Singular & Pluural \\
\hline Illatiiv & $\operatorname{ranko/n}(a)(<\operatorname{sgak}+$ pp $*$ nā $)$ & rankos/na $\quad(<$ plak + pp $*$ nā $)$ \\
\hline Inessiiv & ${ }^{*}$ rankāj/en $(<\operatorname{sglok}+$ pp *nā $)$ & $\begin{array}{l}\text { rankosu / rankosa / rankose }< \\
\text { plak }+? \text { pp *-én }\end{array}$ \\
\hline Elatiiv & - & - \\
\hline Allatiiv & rankos/pi $(<\mathrm{sgg}+\mathrm{pp} *$ pie $)$ & $\mathrm{rankum} / \mathrm{pi} \quad(<\mathrm{plg}+\mathrm{pp} * \mathrm{pie})$ \\
\hline Adessiiv & rankai/pi $\quad(<$ sglok + pp $*$ pie $)$ & rankosum $/ p i \quad(<$ pllok + pp *pie $)$ \\
\hline Ablatiiv & - & - \\
\hline
\end{tabular}


Uurijate tähelepanu on köitnud veel leedu imperatiiviparadigma vormide $k i$-formant (vanaleedu keeles ja murdeti ka -ke-). Vene baltoloogid Vladimir Toporov ja Oleg Trubačev (1962: 249-250) on esitanud balti imperatiiviformandi - $k(i)$ - / -ke- kohta hüpoteesi, et see on soome-ugri päritolu ${ }^{1}$, nagu ka vene imperatiivivormidele liituv partikkel -ka (davaj/ $k a$, rasskaži/ka). Kõnealune formatiiv esineb indoeuroopa keeltest vaid leedu keeles. Pole kahtlust, et tegemist on uuendiga. Leedu $k i$-formatiivi päritolu pole leedu keele ajaloo uurija Zinkevičiuse arvates siiski selge. Zinkevičius esindab seisukohta, et tegemist pole soome-ugri laenuga, kuid on võimalik, et ,meie esivanemad matkisid soome-ugri imperatiiviparadigma malli" (probleemi kohta lähemalt: Zinkevičius 1981: 129-130; 1984: 329; 1987: 219-220; Kazlauskas 1966: 69-72).

Tabel 2. Leedu imperatiiviparadigma: mokyti 'õpetama'

\begin{tabular}{|l|l|}
\hline Singular & Pluural \\
\hline- & moky/ki/me \\
\hline moky/k(i) & moky/ki/te \\
\hline temokai & temokai \\
\hline
\end{tabular}

\section{Eesti-läti keelepiir ja eesti keelesaared Lätis}

Eestlasi ja lätlasi kui naabreid seob pikk, aastasadu kestnud ühine ajalugu, esiajaloolised kokkupuuted aga ulatuvad mitme aastatuhande taha. Arheoloogia- ja onomastikaandmed osutavad, et tänapäeva Põhja- ja Ida-Lätit asustasid kuni 7. sajandini läänemeresoome hõimud - tõenäolisimalt lõunaeestlaste ja liivlaste eelkäijad -, kes aegamisi sulanesid kagust ja lõunast saabuvate balti hõimude hulka. Tegelikult polegi päris selge, kui kaugele lõunasse ja edelasse läänemeresoomeline asustus on ulatunud, sest läänemeresoome tüüpi kohanimesid leidub mõnel määral ka tänapäeva Leedus, Valgevenes, Kaliningradi oblastis ja Poola rannikualadel. Eestiläti etniline piir oli põhijoontes välja kujunenud 13. sajandi alguseks: selleks ajaks olid latgalid, tulevase läti rahva tuumik, jõudnud eestlaste (ja liivlaste) keeleala naabrusse (Vaba 1997: 28 jj). Sellised lõunaeestilised keelesaared nagu Leivu ja Lutsi püsisid balti asustuse keskel aga

${ }^{1} k$-tunnuseline imperatiiv puudub vaid mari keeles ja permi keeltes. 
aastasadu, hääbudes 1970.-1980. aastate paiku. Seega on meil tegemist autohtoonsete ehk põliste eestlastega Läti pinnal. Leivud ja lutsid on ainsad Lätis elanud põliseestlased, kellelt on keeleainest talletatud küllaltki süstemaatiliselt.

Andreas Johan Sjögreni andmeil oli 1847. a leivusid üle 2500. Piirnevate alade ümberrahvustumist silmas pidades püsis väikesearvuline leivu kõnelejaskond lätikeelses ümbruses üllatavalt pikka aega. Seda soodustas vähemalt kaks asjaolu: suhteline eraldatus läti asualadest ja suur paiksus, sest talurahva liikumispiirangud kestsid veel pärast pärisorjuse kaotamistki. Leivude järkjärguline lätistumine on kirjanduses suhteliselt hästi dokumenteeritud. Leivusid puudutavas kirjanduses on pikka aega püsinud teema, kas leivud pole siiski liivlased, ehkki leivude lõunaeestlus tõestati juba 18. sajandi teisel poolel. Leivu murraku foneetilised, grammatilised ja sõnavaralised uuendused, mis on spetsiifiliselt ühised liivi keelega, tulenevad läti laenuallika mõjust nii Leivu murrakule kui ka liivi keelele (Vaba 1997: 39 jj).

Oskar Kallas käis lutside juures uurimisreisil 1893. a. Tema hinnangul oli neid tollal 4387, emakeele kõnelejaid umbes 800 . Rõhutatult suulisele pärimusele toetudes on Lutsi keelesaart käsitlevas kirjanduses hakanud domineerima arvamus, et lutsid on sisserändajad Kagu-Võrumaalt setude naabrusest. Oletatav väljarändamine olevat toimunud kas 17. või hiljemalt 18. sajandi algusaastail laastava Põhjasõja tõttu. Väljarännuhüpoteesi kohta on kogutud materjali ka leivudelt, mis enamasti on aga hilist kirjanduslikku algupära. Rännuhüpotees eeldab suurte inimhulkade liikvelolekut, mille kohta ajalooallikad mingit tuge ei paku. Tähelepanuväärne on siinkirjutaja arvates seegi, et keelesaarte läti keeleainesest üleküllastatud leksikon ei sisalda läti algupära maastikusõnu, mis kõneleb ilmekalt eesti keelesaarte autohtoonsusest. Lutside puhul on tähelepanu pööratud veel sellele, et Lutsi murre polnud nii ,rikutud”, mis just nagu peaks tõendama lutside hilist saabumist võõrasse keele- ja kultuurikeskkonda. Lutside keele suurem ,puhtus” seletub pigem Latgale etnilise mosaiiksuse ja mitmekultuurilisusega ning tõsiasjaga, et Ida-Lätis polnud pikka aega ühtki dominantset (prevaleerivat) keelt, mis oleks soodustanud ja kiirendanud enamuskeelde sulandumist. Vene keel kujunes Latgales elavate etniliste rühmade vaheliseks suhtluskeeleks alles 19. sajandil (Ariste 1962: 550). Kallas (1894: 12) on lutside etnilist ja keelelist olukorda iseloomustanud tabavalt: „rahvuste pudru seas elab meie Eesti rahva unustatud suguharu”. 
Asjaomases kirjanduses leidub veenvaid näiteid selle kohta, kuidas antropoloogiline ja etniline heterogeensus aitab vähemustel kauem ja paremini alal hoida etnilist omapära, incl. keelt. Selles mõttes olid leivud hoopis teiselaadses olukorras (Vaba 1997: 33 jj).

Päriseesti keelealal on umbes 370 uuemat läti laentüve, millest suurem osa on registreeritud Lätiga külgnevatelt aladelt, peamiselt küll Kagu-Eestist: Harglast 176, Karulast 73, Häädemeestelt 89 ning Hallistest 57. Piiriäärsete alade läti-eesti kontakte elavdas kohatine segaasustus (vt täpsemalt Vaba 1997: 28 jj). Lätis paiknenud lõunaeesti keelesaarte sõnavaras on ligi 900 läti tüve: Leivus 719, Lutsis 173 . Keelekontaktide üks peamisi universaale on teatavasti sõnastatud nii: mitteleksikaalne laenamine on võimalik ainult juhul, kui samast keelest on saadud ka leksikaalseid laene. Sõnavaralaenud on piltlikult väljendades pinnast ettevalmistav kahurituli morfoloogiliste ja süntaktiliste laenude vastuvõtuks ning võivad seega anda märku võimalikest morfoloogilistest ja süntaktilistest laenudest ja pakkuda uurijale taustatuge nende väljaselgitamiseks.

Asjaomases kirjanduses on väljendatud küll ka seisukohta, et mitteleksikaalne laenamine ei eelda tingimata eelnevat leksikaalsete laenude tulva. Keelekasutus ei ole täiesti alateadlik tegevus: seda mõjutavad ja muudavad inimeste uskumused, ilutaotlus, patriotism jne, mis võivad olla tõkestavaks filtriks, kusjuures süntaktilised konstruktsioonid, mida nii selgesti ei tajuta ega osata liigitada omaks ja võõraks, levivad läbi filtri. Hea näide on läti verbiprefiksite teadlik eiramine mõnede liivi keele kasutajate poolt. Nimetatud asjaoluga tõuseb päevakorda kogutud materjali kvaliteet. Läänemeresoome keelte materjali kogumisel on välitöödel kasutatud metoodika võinud jätta jälje saadud tulemustesse. Praeguse teema puhul puudutab see vähemalt osaliselt varasemat leivu keelematerjali, mida koguti tõlkemeetodil Bacmeisteri küsimustikuga (sks die Bacmeisterschen Sprachproben): nii on näitelauseisse sugenenud ohtralt süntaktilisi lätipärasusi. Artikli autor on sellele tõigale tähelepanu juhtinud (vt Vaba 1991: 83-84, märkus 4). Ka keelejuhiti võib võõra keele mõju ulatus erineda. Nii on Valter Niilus leidnud, et 1930. aastail oma elava ja voolava kõne tõttu murdeuurimise keskpunktis olnud Leivu keelejuhi Alide Petersoni (1876-1938) idiolekt „,sisaldas .. pisut rohkem lätimõjulisi moodustisi ja tõlkelaene kui mõne teise leivu murde kõneleja oma" (Niilus 1938a: 255). 


\section{Läti-eesti keelekontakti iseloom}

Läti-eesti ja eesti-läti kontaktid on ajaloolisel ajal olnud ja on praeguseni valdavalt keeleülesed, need on toimunud ja toimuvad prevaleerivate keelte vahendusel. Öeldut võib tabavalt ilmestada Valgas sirgunud Valve Saretoki remargiga 1920. aastatest: „Minu isa suureks kurvastuseks oli, et meie õega kunagi läti keelt päriselt ära ei õppinud .. Aga meie sugupõlv ei vaevunud õppima enam naabri keelt, kui sai hakkama ka saksa või inglise keelega .." (Vaba 1999: 539). Uuema aja eesti-läti ja läti-eesti kakskeelsus on toimelnud ja toimleb esmajoones kitsamas segaperekondade ringis. Perekondlik pitser iseloomustab eesti-läti keele- ja kultuurikontakte laiemaltki, mille ilmekaks näiteks on eesti lätilaenulise sõnavara sisuplaan, kus domineerib koduse eluga (joogid-söögid, rõivad) seotud sõnavara.

Nii eesti kui ka läti keelt on mõjutanud ja mõjutavad üha kolm jõulist kontaktkeelt: saksa, vene ja inglise keel, kusjuures vene keele mõju püsib endiselt esiplaanil vähemalt Lätis. Ajaloolistest ja sotsiolingvistilistest teguritest olenevalt on saksa keele mõju läti keelele olnud väga ulatuslik, tõenäoliselt ulatuslikum kui saksa mõju eesti keelele. Seda asjaolu võib ilmestada kas või sellise statistikaga: eesti kirja- ja ühiskeeles on läti keele vahendusel saadud saksa laentüvesid 19\%, Leivu keelesaarel aga koguni 37\% kõigist murrakus registreeritud läti laenudest (Vaba 1997: 446).

Tänapäeva läti rahva ja keele kujunemises on osalenud latgalid, semgalid, seelid ja kuršid. Need neli balti hõimu elasid suurel osal tänapäeva Läti alast veel 9. sajandil. Tulevastesse lätlastesse on sulanud tähelepanuväärsel hulgal läänemeresoomlasi (liivlased ja (lõuna)eestlased, Bauska piirkonda sõjavangidena deporteeritud vadjalased ehk kreevinid) ning idaslaavi idiolektide kõnelejaid (venelased, valgevenelased ja poolakad). Nõnda on läti keel oma levikualal vägagi mitmepalgeline ja kontaktiuurijal tuleb arvestada vahestiste substraadi-, adstraadi-ja superstraadinähtustega. Läti kirjakeel rajaneb keskmurdel, mida on kõneldud Läti keskosas Eesti piirist põhjas kuni Leedu piirini lõunas. Võrreldes leedu keelega on läti keele morfoloogiline struktuur mõnevõrra lihtsustunud. Selle üheks põhjuseks peetakse läänemeresoome keelte, eriti liivi keele mõju. 


\section{Balti-läänemeresoome keeleliit}

Keeleajalugu ei saa vaadelda lahus muust kultuuriloost, seega on riskantne väita, et esiajalooliste keelte areng olnuks täiesti analoogiline nüüdisaegsete keelte arenguga. Balti-läänemeresoome väga pikaajalises, aastatuhandeid kestnud keelekontaktis on muutused ja mõju liikunud vastastikku üle keelepiiride, viinud mh ühisarenguteni (konvergents), mille seletamine laenudeks ei ole vägivallata võimalik. See, kuidas keeled reaalselt igas situatsioonis üksteist mõjutavad, on komplitseeritud. Ei saa kõrvale jätta võimalikke rööparenguid, keele süsteemisisese arengu mõju. Läti-eesti kontaktidest kõneldes ei tohi unustada, et mõlemat keelt on mõjutanud samad kontaktkeeled. Arvukaid keeleüleseid isoglosse silmas pidades on täiesti õigustatult hakatud rääkima balti-läänemeresoome keeleliidust kui geneetiliselt erinevate keelte liidust. Balti või kahe ülestikuse keeleliidu - Baltoskandia ja Hansa keeleliidu teemat on arendatud peaaegu terve sajand. Sellised keeleliidu (sks Sprachbund) teooria arendajad nagu Nikolai Trubetzkoy (termini Sprachbund esmakasutaja) ja Roman Jakobson on rääkinud ruumitegurist ja kasutanud õlilaigu metafoori: keelenähtused võivad liikuda tuumalast väljapoole. Keeleliidu või keeleliitude mõjuväljas olemine on tugevasti mõjutanud liivi ja eesti, vähemal määral vadja keele arengut, kuid mitte nii väga soome keele arengut. Indoeuroopa keeltest on Baltoskandia ja Hansa keeleliidu mõjusfääris osalenud läti, taani, rootsi, norra ja alamsaksa keel, marginaalsemalt leedu ja vanapreisi (muinaspreisi), põhjapoola (Pommeri ja Kašuubi piirkond) ja ülemsaksa keel. Keeleliidu teema kohta leidub palju kirjandust.

Grammatikas avaldub võõrmõju vormiainese kohandumisena võõraste struktuurimallidega, aga ka otsese laenamisena, seejuures keele struktuurimallide kohandamine kontaktkeele mallidega peab alati olema kooskõlas selle keele enda struktuurilise eripära ja arengusuundadega (Blokland, Kehayov 2010: 42). Grammatikauuenduste juurdumist mõjutavad struktuurisobivus, kasutuspotentsiaal ja tendentsisobivus (Metslang 1996: 88-89). Eesti ja läti keelt iseloomustavad arvukad morfosüntaktilised sarnasused, mida enamasti ei saa seletada (hilise) läti mõjuga. Balti ja läänemeresoome keelte konvergentsinähtustest on nüüdseks sugenenud juba üpris ulatuslik kirjandus. Balti või kitsamalt eesti ja läti keele fonoloogilisi ja morfosüntaktilisi ühisjooni on käsitletud tüpoloogia ja areaalitüpoloogia kontekstis. Thomas Stolz on väga paljude uurijate töö tulemused kogunud sageli tsiteeritud üllitiseks ,Sprachbund im Balticum? Estnisch und 
Lettisch im Zentrum einer sprachlichen Konvergenzlandschaft" (1991). Lähema vaatluse alla on Stolz võtnud sellised morfosüntaktilised ühisjooned nagu kvotatiivi, analüütilise superlatiivi, possessiivpronoomenid, refleksiivuse väljendamise, interrogatiiv- ja relatiivpronoomenid, küsivuse topeltmarkeerimise lause alguse ja lõpu partikliga, eitusverbi taandumise (defleksioon), haben-konstruktsiooni, rea samalaadseid debitiivi väljendamise võimalusi, ühisjooned adpositsioonide süsteemis. Liena Muižniece, Helle Metslang ja Karl Pajusalu on uurinud kõrvutavalt eesti ja läti keele mineviku partitsiibi finiidistumist (Muižniece jt 1999). Nad nendivad, et eesti ja läti keeles on mineviku predikaatpartitsiipide funktsioonid ja finiidistumise kulg paljus sarnane, lisades: „Neid sarnasusi ei saa seletada üksnes naaberkeelte hiliste kontaktidega .., on aga võidud saada vastastikusi mõjutusi ning oldud ka koos kolmandate keelte mõjuväljas."

Toodud loetelu ei ammenda kaugeltki eesti ja läti keele ühiseid rööpsusi. Huvipakkuv rööbik on seotud arengutega pöördekategoorias. Oleviku ainsuse 3. pööre on ühes lõunaeesti verbiklassis teatavasti lõputa, nt $a$ 'nd 'annab', jû 'joob', tulõ 'tuleb' (Keem, Käsi 2002: 47). Seda on seletatud olevikutunnuse *- $\beta i$ kadumisega (Setälä 1899: 98-99) või kindla kõneviisi lihtmineviku muutevormistiku eeskujul tekkinud analoogiaga (Kettunen 1962: 85), muudes läänemeresoome keeltes on see aga markeeritud olevikutunnuse *-pi / *- $\beta i$ jätkajatega (Rätsep 1989: 1508). Balti keeled pakuvad siin huvitava rööbiku: juba balti algkeelest peale on temaatiliste verbide ainsuse ja mitmuse (keeleajalooliselt ka kaksuse) 3. pööre olnud ja on puhas lõputa tüvi (Zinkevičius 1984: 219 jj), nt ld kalba ja 1t runā 'räägib, räägivad'.

Nii eesti kui ka läti kvotatiiv, samuti eesti jussiiv ning sellele funktsioonilt ja osalt moodustusmallilt vastav läti kaudse kõneviisi käsuvorm (atstāstījuma izteiksmes pavēles paveids, vt MLLVG I: 626) on tekkinud kummagi keele hilises arengufaasis ilma pöördelõppudeta. Leedu keeles on kaudse kõneviisi areng jäänud algusfaasi (Endzelīns 1951: 976 jj). Tänapäeva läti keeles on tingiv kõneviis isikulõppudeta ja ka eesti keeles on lõppudeta paradigma rööpselt isikulõpulisega võimalik, seda aktsepteerib ka keelenorm. Balti tingiv kõneviis kujunes idabalti keelefaasis ja selle vormistik moodustati pöördelõppudega (Zinkevičius 1984: 329-330; 1987: 222). Ka tänapäeva leedu tingiva kõneviisi ainsuse 1. ning mitmuse 1. ja 2. pööre moodustatakse lõppudega: dirb/č/iau 'töötaksin', dirb/tum 'töötaksid', dirb/tu 'ta töötaks, nad töötaksid', dirb/tu/me 'töötaksime', 
dirb/tu/te 'töötaksite'. Läti kirjakeele tingiv kõneviis moodustatakse supiini abil ja ilma pöördelõppudeta: es, tu, viņš / viņa, mēs, jūss, viņi / vingas stradā/tu 'ma, sa, ta, me, te, nad töötaks'. Läti vanemas kirjakeeles (nt 1753. a evangeeliumitekstis) isikulõpud alles püsivad. Tänapäeval esineb isikulõppudega konditsionaali vaid läti keele (geograafilises mõttes) perifeersetes piirkondades: ülemläti murdekeeles (sh latgali kirjakeeles) ja hajusamalt Kuramaal mõnes liivipärases murrakus (Endzelīns 1951: $893 \mathrm{jj})$.

Eesti vanem põhjaeestiline kirjakeel näitab isikulõppude püsimist tingivas kõneviisis kuni 17. sajandi lõpuni, ent nende kadumist noteerib juba Johann Hornung 1693. a ilmunud keeleõpetuses „Grammatica Esthonica" (lk 71: olleksin minna / olleks minna, olleksime meie / olleks meie jne). Eesti murretest on konditsionaali isikulõpud kõige paremini säilinud kirderanniku- ja idamurdes (Must 1987: 252 jj; Univere 1996: 15; vt ka Saareste 1955: 52, kaart 55: konditsionaali -ksin). Lõunaeesti murretest on konditsionaali pöördelõpud samuti kadunud (Tanning 2004: 117-118; Keem, Käsi 2002: 50). Rätsep märgib, et pöördelõppude taandumine on ainulaadne soome-ugri keeltes (1989: 1517-1518). Kokkuvõtvalt võib tõdeda, et pöördelõppude taandumine tingivast kõneviisist on läti ja eesti keeles alanud peaaegu ühel ajal, kuid läti ühis- ja kirjakeeles on protsess jõudnud pöördumatult isikulõppude kadumiseni. Isikulõppudega konditsionaalivorme (formatiividega $-t u / m$, -tu/t) kasutab nüüdisläti üksikjuhtudel interjektsioonides ( $l \bar{u} g / t u / m$ 'palun = paluksime') ja arhaiseerivates tekstides.

\section{Läti mõju eesti murdekeele grammatikale}

Selge, vaieldamatu läti keele mõju piirneb keelesaarte ja piiriäärsete murdealadega. Ulatuslik läti keele mõju Leivu keelesaarel ilmneb eelkõige foneetikas ja sõnavaras, kuid vaieldamatult ka grammatikas. Alljärgnevalt vaadeldakse läti keelest laenatud morfoloogilisi ja morfosüntaktilisi vahendeid, tuletusliiteid ning sõnamoodustusmalle, mis iseloomustavad eriti leivude keeleuusust ning vähemal määral Lutsi ja päriseesti kontaktvööndi murrakuid. Nagu juba öeldud, iseloomustavad paljud lätilaenulised grammatilised ja morfosüntaktilised ilmingud ka liivi keelt, kuid neil käesolevas lühiuurimuses ei peatuta. 


\subsection{Grammatiline sugu (geenus)}

Indoeuroopa keelte enamikku iseloomustab teatavasti sookategooria. Läti keele grammatika tunneb mees- ja naissugu. Nii on leedugi keeles, kuid seal leidub ka vaieldamatuid jälgi kunagise kesksoo vormidest. Lisada võib sedagi, et läänemeresoome keelte mõned balti laenud viitavad laenuandjas eksisteerinud neutrumile. Läti sookategooria on universaalne, sest grammatilise sootunnuse saavad peaaegu kõik sõnad, kui nende sugu on võimalik liite abil markeerida. Grammatiliste sootunnuste poolest ei erine ainult nimisõnad, vaid ka ase-, omadus-, arv- ja kesksõnad (vt lähemalt Vaba 2006: 18-19). Balti keelte grammatiline sugu on seotud kongruentsiga: viimane on grammatilise soo kõige olemuslikum kriteerium. Nii nagu kogu Uurali keelte rühmas, nii ka läänemeresoome keeltes grammatiline sugu puudub. Grammatiline naissugu on kadunud ka liivi substraadil tekkinud läti keele liivipärastest murrakutest, kuid murdekeele taandudes ilmneb see tänapäeval idiolektiti veel kõnekeeles. Läti slängi iseloomustab sootunnuste teadlik segamine: formaalne meessugu võib märkida ka naissoost isikuid ja vastupidi: ielas meita 'miilits; politseinik = tänavatüdruk', skuķis pro skukse 'tüdruk, plika', sievietis pro sieviete 'naisisik, naine'.

Läänemeresoome keeltesse, sh kirjakeeltesse juurutatud naissugu märkivate liidetega tuletiste kasutamine on fakultatiivse iseloomuga, sugupooli eristatakse eelkõige leksikaalsete vahenditega. Läti-eesti keelekontaktiga ei ole grammatilist sookategooriat laenatud isegi mitte läti keelest väga tugevasti mõjutatud Leivu murrakusse, mis võimaldab taas kord tõdeda, et süsteemile võõrad grammatikakategooriad kas ei juurdu üldse või jäävad laenates marginaalseks nähtuseks.

Läti meessoost noomenite sootunnused $-s,-\check{s}$, $-i s$ (ja $-u s$ ), samuti naissootunnus $-s$ jäävad laenamisel harilikult ära (elisioon: seek 'külimit' $<$ siek/s id., tsepli 'lubjaahi' < cepl/is id.), naissootunnused - a ja -e aga kas 1. kaovad lõpukao tõttu enam kodunenud laenudest (rakan 'nõid'< ragan/a id., tsemm 'raudaas palkide ühendamiseks parves' < cemm/e), 2. transformeeritakse tüvevokaaliks - $a /-\ddot{a},-e /-\tilde{o}$ (lipka 'tinast tursaõng' < blitk/a id., pit'ska / pit'skä 'kanepitemp'< picka id., d'ok't'õ, vrd dakte) või 3. asendatakse muu vokaaliga, sageli $i$-ga (tein' : t'ein' $i$ 'muistne veimevakk, puunõu vilja säilitamiseks', vrd tīna / tīne id.). Probleemi kohta detailsemalt ja lisanäiteid vt Vaba 1997: 410-411, 426-427, 434 jj. 


\subsection{Sootunnused Eesti perekonnanimistu lätitaustalistes perekonnanimedes}

Eesti perekonnanimede süsteem on ühesooline, tänapäeva läti perekonnanimistu aga kahesooline (Lapiņš - Lapiņa). Kahesooline perekonnanimesüsteem loodi Lätis sihiteadliku nimekorraldustöö tulemusena 20. sajandi alguskümnendeil. Algselt kunstlik kahesooline süsteem juurdus Lätis kiiresti ja kindlat seetõttu, et läti keelele on iseloomulik isikut tähistavate nimisõnade hästi arenenud sooline korrelatsioon: praktiliselt igast ametit, elukutset, aunimetust vms märkivast nimisõnast võib tuletada nii meeskui ka naissoost vormi, nt sõnakuju generālis 'kindral' kõrval on mõeldav ka generāle 'naiskindral', prostitūte 'naisprostituut' kõrval ka prostitūts 'meesprostituut'.

Läti perekonnanimede maskuliinse sootunnuse $-s$ ja $-\check{s}$ elisioon on tavaline Eesti perekonnanimistu vanemasse kihistisse kuuluvates lätitaustalistes perekonnanimedes (Vaba 2002: $274 \mathrm{jj}$ ). Meessootunnust $-s,-\check{s}$ (-sh) sisaldavad ins-, ings-, inš-, insh-lõpulised perekonnanimed moodustavad $15 \%$ ja naissootunnust - $a$ sisaldavad ina-, onna-, inja-, õnja-lõpulised nimed $31 \%$ Eesti perekonnanimistu lätitaustalistest $i n$-nimedest. Eestis võivad naisedki kanda maskuliinse tunnusega perekonnanime, kuid lähemad andmed (kui paljud, millistes Eesti piirkondades, miks) selle kohta puuduvad. Naissootunnustega nimede küllalt suur osakaal in-nimede hulgas kõneleb ühelt poolt nende hilisest ilmumisest Eesti perekonnanimistusse, kuid teiselt poolt võib see olla märk paljude sellesse rühma kuuluvate nimede hoopis muust, eelkõige idaslaavi päritolust (Vaba 2004: 52 jj). it-, et-, itis-, its-, ite-, el-, elis-, els-, ele-, ul-, ulis-, uls-, ule-lõpuliste lätitaustaliste nimede kohta Eesti perekonnanimistus vt lähemalt Vaba 2004: 58 jj.

Eesti kohanimistu läti algupära nimedes on sootunnused elideeritud, nt Hel Maardina (talu), Krl Mutsina / Mugina (järv), Puurina (talu), Vas Idina (järv).

\subsection{Plurale tantum-sõnad}

Ainsus- ja mitmussõnade hulk erineb keeliti, kuid tähendusväljad, kuhu need kuuluvad, on enamasti ühised (EKG I: 61-62). Hella Keem ja Inge Käsi on osutanud, et Võru murdes kasutatakse teistsuguseid mitmussõnu kui põhjaeesti või kirjakeeles ja neid on rohkem, nt jahu', ra 'tta ' 'vanker', 
sûrma' 'tangud', rü̈̈ 'rukis' (2002: 38). Nähtus iseloomustab ka keelesaari, nt Lut kaari/keze ' 'vanker', Lei d'ova' 'jahu'. On huvitav märkida, et sama semantikaga mitmussõnad esinevad ka läti ühis-, kirja- ning murdekeeles, nt milti 'jahu', rati 'vanker', putraimi 'tangud', ratini pl 'käru, käsivanker', rudzi 'rukis' (LES), $\operatorname{ltg} b$ 'olst' $i$ m'ilst' $i$ 'valged jahud = nisujahu', rot' $i$ 'rattad = vanker', rudz'i 'rukis' (Reksēna 1998 I-II).

\subsection{Superlatiivsuse väljendamine}

Läti tavalisim superlatiiv ja eesti analüütiline superlatiiv moodustatakse teatavasti samamoodi: partikkel (= pronoomeni viss plg visu resp. pronoomeni kõik sgg) + võrdlussõna keskvõrde vorm, nt visu skaist/āk/ais $>$ vis/skaist/āk/ais - kõige kauni/m. Läti kõne- ja murdekeeles on peale ülalkirjeldatud tavapärase superlatiivi moodustusviisi hulgaliselt muid objekti omaduse maksimaalse intensiivsusastme väljendamise viise (MLLVG I: 464 jj.). Mõned neist on tulnud kasutusele Leivu murrakus, kus tavalisim vormimall maksimaalse intensiivsusastme väljendamiseks on ül' eba 'rohkem, enam' + võrdlussõna algvõrre / adverb, nt ül' eba so ‘ur 'kõige suurem': ta d'êzu 's "o 'm ül' eba so 'ur ķü ön'ig 'see Jeesus on kõige suurem kuningas' (Niilus 1937: 27, vt ka ibid.: 69-70), ül' eba + illu 's 'kõige ilusam'. Vormimall lähtub läti keelest: $p \bar{a} r \bar{a} k(=p \bar{a} r$ 'üle' + keskvõrde tunnus - $\bar{a} k$ ) 'liiga, ülearu' + võrdlussõna algvõrre / adverb, nt pārāk dārgs 'liiga, ülearu kallis', pārāk daudz 'liiga palju'. ${ }^{2}$ Niilus (1937: 70) on seda Leivu moodustusviisi võrrelnud Hargla esinemusega: ‘iiba soolanõ 'väga soolane', ‘iba suur 'väga suur'. Ent Hargla ‘iiba etümoloogia on ebaselge. Läti keele eeskujul on Leivu murrakus väljendatud omaduse suurt määra ka lätilaenulise tõhustava adverbiga mûž'igadõ 'väga, täiesti, igavesti' < lt mūǔ̌̀gi adv id. < mūǔ̌̀gs adj 'eluaegne, igavene' (Vaba 1997: 320): kumball_om_mûž'igadõ äste 'kellel on väga hästi' (Niilus 1937: 16).

Hargla murrakus väljendatakse omaduse suuremat määra tarindiga intensiivistav adverb häste + komparatiiv, nt tā poi skõnõ om häste sūrõmb ku tü 'tru 'kla 't's 'see poiss on (palju) suurem kui tüdruklaps' (Keem, Käsi 2002: 44). Tarindile on täpne vaste idaläti murdekeeles, sh Latgales:

${ }^{2}$ Murdenäidete transkriptsiooni on siin ja edaspidi mõnevõrra lihtsustatud. 
Muk'uona Stas's' lab'i vacuôks p 'uis's' b'ie p 'ar man'i 'M. S. hästi vanem poiss oli minust $=$ M. S. oli minust vanem (= hästi vanem) poiss' (Reķēna 1998 I: 545 sub lab'i).

\subsection{Konditsionaal}

Muižniece, Metslang ja Pajusalu on lõunaeesti idapoolsete ja idaläti murrete silmatorkava spetsiifilise ühisjoonena esile toonud mineviku partitsiibi kasutamise tingiva kõneviisi oleviku tähenduses, nt tiiq võinuq tullaq 'te võiksite tulla' (Muižniece jt 1999: 534); nii ka Lutsi murdes: Jooze v'aene ümbre tule, / Kab kä'eken es palanu' Jookseb vaene ümber tule, et käekene ei põleks = ei põlenud' (Kallas 1894: 83), ma tulnu' 'tuleksin = tulnud' (Sang 1936: 406). Autorid peavad seda abiverbita mineviku partitsiibi finiidistumise üheks kõige ilmekamaks osutuseks. Läti murdeuurija A. Elksnītise järgi on nähtus registreeritud järgmistes pagastites (murrakutes): Lazdona, Prauliena, Sarkaņi, Patkule, Cesvaine ja Dzelzava pagastis (FBR IX 1929: 154). Esitatud läti näiteid on siiski võimalik alternatiivselt tõlgendada kui konditsionaali elliptilise perfekti vorme: $k a(b)$ tu vysu zynuojus 'ae, .. gaužuok rauduotul' $i$ '= ja tu visu būtu zinājusi / zinātu - raudātu vēl gaužāk / kui sa kõike oleks teadnud / teaks - nutaks veel kibedamini' (vt ka Endzelīns 1951: 974). Muide, dainanäide ongi Muižniece jt artiklis tõlgitud perfektiga: Kaut ieviņa vēl ziedējuse 'Kui (oleks) toomingas veel õitsenud' (1999: 526). Ka Keem ja Käsi on selliseid juhte tõlgendanud konditsionaali perfektiks, nt $s a^{k} \_$kirutanu kirutamist 'sa oleksid kogu aeg aina kirjutanud' (2002: 21).

\subsection{Debitiiv}

Läti keeles väljendatakse deontilist ehk kohustuslikku vajadust ('on vaja, on tarvis') erilise kõneviisi, debitiiviga. Läti debitiiv moodustatakse järgmiselt: keeleajalooliselt pronominaalset päritolu liide $j \bar{a}-+$ ind prees $\mathrm{sg}$ / pl 3. p (MLLVG I: 615 jj). Agent seostub debitiivivormidega daativis: man (ir) jāiet 'ma pean minema = mul on minemine'. Nüüdisläti keeles täheldatakse debitiivi kasutussageduse selget vähenemist (Bušs 1999: 519). Leedu keel ei tunne debitiivi.

Läti keele debitiiv on olnud eeskujuks vastava malli tekkele keelesaartel: agent $_{\text {adess }}+$ olema-verbi sg $3 \cdot \mathrm{p}+$ teonimi $/ k$-liiteline deverbaal $_{\text {sgn }}$ : 
Lut Sul iks on [sic!] minemine kưu 'sa pead ikka koju minema' (Kallas 1894: 29); Lei mull_om min'e $k$ ' $k$ 'aõma 'ma pean vaatama minema' (Niilus 1937: 13), tuul ó 'm k'uulmi 'n 'ta peab surema' (ibid.: 25), ku mull_a'm mie 'kt adi_bulõ u'n t'ulõ ka tâš' $t$ 'mi n' 'et ma pean tädi juurde minema ja talle ka rääkima' (ibid.: 27), bõ ‘t pu ojal "olnudõ mie 'k mõ `ttsa jelama 'aga poeg olevat pidanud minema metsa elama' (ibid.: 34), mull om min'ek / min'emin 'ma pean minema' (Nigol 1970: 65). Kirjeldatud debitiivikonstruktsioon esineb ka liivi keeles: um luggõmõst, kuid teonimi on liivi keeles ainsuse osastavas. Liivi keeles võib olema-verb peale indikatiivi esineda ka kvotatiivis ja konditsionaalis.

\subsection{Optatiiv}

Optatiivi (ehk desideratiivi ehk soovivat kõneviisi) on Lätiga piirnevates Häädemeeste ja Karksi murrakus väljendatud kest-formatiivi abil, mis on algupäraselt deminutiivliite -kene sgp -kest: Hää ei nut'ukest'ära nuta', Krk kor'gakest 'korja', võtakest 'võta' jt. Deminutiivse optatiivi kohta on andmeid vanapärasest Karksi murrakust, kus seda on tarvitatud eelkõige väikese lapse kõnetamisel (Pajusalu 1989: 142). Pajusalu seostab deminutiivse optatiivi kasutuselevõttu suhtluspartnerite lähedust rõhutava keelekasutusega. Analoogiline nähtus on laialt levinud läti hoidjakeeles, mida iseloomustab silmatorkavalt rohke deminutiivide kasutamine (vt „6. Läti mõju sõnamoodustuses”): deminutiivliite -iņ- võib peale noomenite ja adverbide liituda ka verbidele, nt čučèt $\rightarrow$ čuč/iņ/āt 'tuduma', iet $\rightarrow$ iet/iņ/āt 'minema, käima', kakāat $\rightarrow$ kaks/iņ/āt 'kakama', nākt $\rightarrow n \bar{a} k /$ iņ/āt 'tulema', ninnāt $\rightarrow$ ninn/iņ/āt 'jooma', sēdēt $\rightarrow$ sēd/iņ/āt 'istuma', $s t \bar{a} v \bar{e} t \rightarrow s t \bar{a} v / i n g / \bar{a} t$ 'seisma' (näited allikaist ME; EH; Rūkse-Draviņa 1961: 85-91; 1977: 239-240). Artikli autorile kättesaadav materjal osutab selgelt, et deminutiivliitega verbide pöördelistest vormidest kasutatakse eranditult ainult imperatiivi ainsuse 2. pööret funktsioonis, mida Pajusalu eeskujul

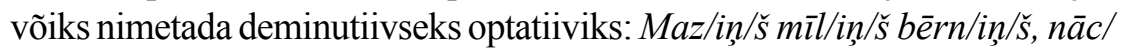
iņ/ās šurp! 'väike (dem) armas (dem) laps (dem), tule (dem) siia!', čuč/ in $/ \bar{a}$ 'tudu (öeldakse lapsele) - schlafe, mache ein Schläfchen (zu einem Kinde)', nāc-ing-ā! 'tule (lapsuke) - komm (du Kleiner)', sēdi/ñā, mans

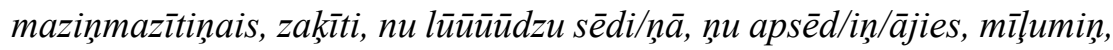
dabūsi kārumiņu .. 'istu (dem), mu pisitillukesekene, jänkukene, no palun istu (dem), no istu (dem + refl), kullake, saad maiuspalakese ..' (näited 
allikaist Rūķe-Draviņa 1977: 239-240; ME I: 418; ME II: 698; Internet). Deminutiivse optatiivi marginaalne levik eesti keeleala lõunapiiril viitab võimalikule läti eeskujule.

\subsection{Verbitarindi finiitverb + sama verbi teonimi tõhususreduplikatsioon}

Sellele Hargla murrakus esinevale tarindile juhivad tähelepanu Keem ja Käsi (2002: 21): $s a^{k}$ kirutanu kirutamist 'sa oleksid kogu aeg aina kirjutanud'. Läti keeles on kirjeldatud tõhususreduplikatsioon väga tavaline, nt līst ar lǐšanu 'muudkui voolab / kallab / sajab = voolab voolamisega': benzīns cilindrā līst ar lïšanu 'bensiin muudkui voolab silindris'; tecēt ar tecēšanu 'muudkui jookseb = jookseb jooksmisega': üdens ar tecēšanu sāka tecēt 'vesi hakkas kõvasti voolama', ne tek ar tecēšanu 'ei voola kõvasti = ei voola voolamisega'. Mati Erelti ja Matti Punttila soome-ugri keelte tõhusreduplikatsiooni käsitlevas artiklis on näiteid teonimega tõhustatud reduplikatsioonitüübi kohta vaid soome keelest (1999: 8). Kirjeldatud reduplikatsioonitüübi marginaalne levik eesti keeleala lõunapiiril viitab võimalikule läti eeskujule.

Niilus avaldas 1938. a artikli „Reduplikatiivsõnadest” (1938b), kus ta väljendab arvamust, et Leivu olevat ,ainus eesti murre, kus allakirjutanu teades reduplitseerimisprintsiip on veel praegugi üsna elujõuline". See on ilmselt inspireeritud läti keelest, kus reduplitseerimisvõimaluste hulgas on väga iseloomulik intensiivistava genitiivi lisamine samatüvelise nimisõna resp. omadussõna ette, nt pār kalnu kalniem 'üle kõrgete mägede = üle mägede mägede' (kvantiteeti augmenteeriv funktsioon), mīkstu mīkstie pēlli 'pehmemast pehmemad sulekotid $=$ pehmete pehmed sulekotid' (kvaliteeti intensiivistav funktsioon). Enamikule Niiluse esitatud Leivu näidetele leidub täpne reduplikatiivvaste lätist: 'al'i_al'l'a 's 'üsna, päris haljas' - zaļ/zalšs / zaļum/zaļš, ill 'u-il 'uza 'väga ilusad' - skaistum/skaisti, š'in' 'i_š'in'n'i n 'sini-sinine' - zil/zils / zilumzils, väigu-, väiku-väikuke 'väga väike' - mazum/mazais jt. On oluline rõhutada, et kirjeldatud läti reduplikatsioonitüübis ei esine korratava põhisõna tüveosa olulist häälikulist ega tähenduslikku deformatsiooni. Tegemist pole kivinenud väljenditega, vaid regulaarse moodustusmalliga. Samalaadset reduplikatsiooni tunneb (piiratult) ka eesti ühis- ja kirjakeel, nt lollide loll 'väga loll', varaste varas 'suur varas' vms. 


\subsection{Lätipärased verbirektsioonid}

Neid võib täheldada Leivu murrakus, nt tahtuma + adess: Lei ku tü ‘ŗigul ta 'htunu 'et tüdruk tahtnud' (Niilus 1937: 55), vai su'l ka `h la `s tah `tunu kord'ada' 'kas sa ka oleksid tahtnud lugeda' (Nigol 1955: 149), vrd lt gribēties + daat 'millegi järele vajadust tundma, tahtma, soovi omama'.

\subsection{Pronoomenisüsteem}

Tõdemus, et grammatilise funktsiooniga sõnu (partikleid, adverbe, proadverbe, adpositsioone, afiksaaladverbe, modaaladverbe, konjunktsioone, interjektsioone, emfaatilisi partikleid) laenatakse hõlpsalt (vt nt Blokland, Kehayov 2010: 35 jj), leiab kinnitust ka eesti-läti kontaktis intensiivselt osalenud murdekeele grammatikas. Pronoomenid on teatavasti suletud sõnaklass, kuhu erinevalt substantiividest hõlpsasti uusi liikmeid ei lisandu. Siiski on Leivust registreeritud lätilähtene interrogatiivpronoomen kas 'mis', vrd lt kas 'kes, mis', kuid siin võib tegemist olla ka individuaalse juhulaenuga, mis on väga iseloomulik nähtus taanduva kakskeelsuse olukorras (Vaba 1997: 289).

\subsubsection{Lõunaeesti demonstratiivpronoomenite kolmeliikmeline süsteem}

Eesti kirjakeeles ja põhjaeestilises murdekeeles on see ja too tähenduserinevus (idiolektiti) neutraliseerunud: tegelikult kasutatakse vaid demonstratiivpronoomenit see, mis osutab ajas või ruumis nii lähedasemale kui ka kaugemale entiteedile (EKG I: 29). Lõunaeesti keeleala, sh keelesaari aga iseloomustab kolmeliikmeline demonstratiivisüsteem: seo / s'joo (harilikult otse kõneleja juures asuva kohta) - taa (harilikult lähiümbruses asuva kohta) - tuu (harilikult endast kaugemal asuva kohta) (vt Keem 1997: 40; Keem, Käsi 2002: 44; VES). Balti algkeelele tagasiviidav demonstratiivpronoomenite kolmeliikmeline süsteem (Zinkevičius 1984: 209 *šis / *is - *tas - *anas) püsib mõnevõrra modifitseerununa läti ühis- ja kirjakeeles ning latgali kirja- ja murdekeeles: It šis / š̃ (kõneleja seisukohalt lähiümbruses asuva kohta) - tas / tā (kaugema ja abstraktsema kohta) viņš / viņa (veel kaugema kohta) (MLLVG I: 513-514); ltg itys / itei / šys / šei 'see' (harilikult lähiümbruses oleva kohta) - tys / tei (neutraalne), 
viņš / vinga (endast kaugemal asuva kohta) (Leikuma 2003: 22). Nii nagu põhjaeesti see / too, nii ka läti kirja- ja ühiskeeles võib šis / šl ja tas / tā tähenduserinevus olla neutraliseerunud (MLLVG I: 518). On mõeldav, et Ida-Läti murdekeel on toetanud lõunaeesti demonstratiivpronoomenite kolmeliikmelise süsteemi püsimist.

\subsubsection{Leivu artiklilaadne demonstratiivpronoomen $t a$}

Läti keelele on iseloomulik demonstratiivpronoomeni tas / tā artiklilaadne kasutamine. Tegemist on saksa kui artiklikeele mõjuga. Sama fenomen iseloomustab teatavasti nii läti kui ka eesti vanemat (tõlkelist) kirjasõna, vrd Neitsinnazet enge ei pea teije mitte söhma: Sedda Adlerri, sedda hauwkast, seda kallakawwi (Gutslaff 1649-56: 5Ms 14 < SC 1992: 118). Läti keelele, eriti kõnekeelele on tas / tā artiklilaadne kasutamine väga iseloomulik ka tänapäeval (Endzelīns 1951: 534; MLLVG I: 519), mistõttu see kuulub 50 kõige sagedasema läti sõna hulka: $t a s$ / $t \bar{a}$ sagedus on üle viie korra kõrgem kui demonstratiivpronoomenil šis / šĭ. Demonstratiivpronoomeni ta lätipärast kasutust võib täheldada ka Leivus (Vaba

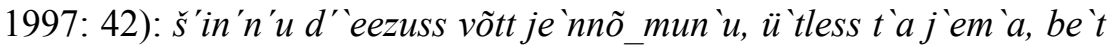
ta la 't's' eij_uz 'u 'sind Jeesus võtab enda juurde, ütleb see ema, aga see laps ei usu' (Niilus 1937: 26).

\subsubsection{Lätimõjulised pronoomenid ja proadverbid}

Lätilaenuline partikkel $k o$ ' $t$ 's' $^{\prime} / k^{u} o$ ' $t$ 's's' 'kas või; mis tahes' $(<1 \mathrm{lt}$ murd koč id. < vlgvn hocb või pl choc' EH I: 637; vt ka Reķēna I: 510 sub koč²) moodustab Leivu murrakus koos järgneva pronoomeniga umbmäärase mööndust märkiva ühendi: $k^{u} o t^{\prime}$ š kumb 'ükskõik kes, ükskõik milline', $k^{u} O{ }^{\prime} t{ }^{\prime}{ }^{\prime}$ mi a 'ükskõik mida, mida tahes', $k^{u} O{ }^{\prime} t{ }^{\prime} s^{\prime} m$ ' $a \ddot{r}$ 'än 'ükskõik missugune, missugune tahes' (vt ka Niilus 1937: 58; 1940: 27-28).

Leivu murrakus esinevad järgmised tõlkelised pronoomenid: $t a \_j$ 'ež $i$,

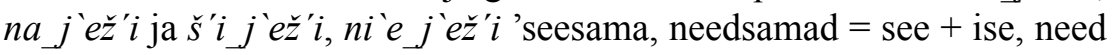
+ ise', vrd lt tas pats, tie paši, šis pats, šie paši id. (ME III: 125 sub pats; Endzelīns 1951: 541), s ära 'n j’ež'i, särttse _j 'ež'i 'just niisugune, just niisugused = säärane + ise, säärased + ise', vrd lt tāds pats / tāds pat, tādi paši / tâdi pat id. (Endzelīns 1951: 541-542), ü 't's's'j ežz'i 'mitte ükski, ei keegi (eitavas lauses); üksainus, üks ja sama = üks + ise': $\ddot{u}$ 'el j ježz’ $i$ 
ei "ollõw ne 'i pi 'kg'kellelgi ei olevat nii pikk [nina]' (Niilus 1940: 20-23; 1937: 49), vrd lt nev.iens pats 'mitte ükski'; viens pats 'ainus, ainuke / nur einer, allein' (ME III: 124 pats).

Paul Alvre (1975: 238-241) arvates on läti tõlkelaen lõunaeesti piiriäärsetes murrakutes (Har, Rõu, Vas, Se) ja Lutsis kasutatav prefiksilaadne edi- / ed'i- / et' $i$ - / idi- / id'i- $(<e i+t e a)$, mis liitub pronoomenite ja depronominaalsete adverbide ette, märkides umbmäärasust: edi/kiä 'ei tea kes, keegi', edi/kohe 'ei tea kuhu, kusagile', edi/ko(h)n 'ei tea kus, kusagil', edi/kost 'ei tea kust, kusagilt', edi/kui 'ei tea kuidas, kuidagiviisi', edi/kuna 'ei tea kunas, kunagi', edi/miä 'ei tea mis, miski' (VES); edi/ kelles, et 'i/kel 'kellelgi', et 'i/kelle 'kellelegi', edi/kohe / et'i/kohe 'kusagile, kuskile', edi/kon = et'i/koh 'kusagil, kuskil', edi/kui = et'i/kui 'kuidagi(viisi)' jt (VKM VI: 692): Rõu Merehn vai edikon üldäss ka ollõv eherüiisi 'Meres või tea(b) kus (= ei tea kus) öeldakse ka olevat (jõe) forelle' (ibid.: 605), Mat_tul'li 'ves'kist vai edikost.. 'ma tulin veskilt või tea(b) kust (= ei tea kust) ..'(ibid.: 669), Juudiv_vai edi ${ }^{k} \_k i n k$ nimä' ol'li' 'Juudi või tea(b) kes (= ei tea kes) nad olid' (ibid.: 669), Tiiä́m_miä timä must 'tahtõ .. 'tea mida (= [ei ] tea mida) ta must tahtis ..' (ibid.: 661). ed'i esineb ka iseseisvalt, nt edi 'ei tea'.

Eventuaalselt tõlkelaenuline edi jt lähtuvad läti indefiniitsetes pronoomenites ja proadverbides sageli kasutatavast prefiksist (partiklist) nez / nezi (ltg naz / nazyn) 'ei tea, mine tea' < ne/zin 'ei + tea', nt nez kāpēc 'tea(b) miks', nez no kurienes 'tea(b) kust' jne. Alvre andmeil ei ole teistes soome-ugri keeltes sellist derivatsioonitüüpi. Prefiksite abil pronoomenite tuletamine on eesti kirjakeelele üldiselt võõras, vt siiski eikeegi, eimiski.

Latgali murdekeeles ja leedu keeles esineb indefiniitne prefiks (partikkel) veel järgmisel kujul: ltg kazy / kaz yn < kas zyn 'kes teab' (Reķēna 1998 I: 490-491), ld kaž / kaži / kažin/ kažna / kana < *kas žinā'kes teab', nt kažin kas '(kes) teab kes / tea kes' jt (Kazlauskas 1968: 402; Rosinas 1982: 41).

teadma-verbi analoogiline areng on täheldatav siiski ka eesti kirja- ja ühiskeeles ning soome keeles. Eesti (kes) teab, (ei) tea, ei tea mis jms esinevad ebaselgust, ebamäärasust, teadmataolu, kõhklust, kahtlust väljendavates ühendites: Ei tea kelle sigitatud sant. Teab mis mees tast saab. On tea kuhu kadunud. Jooksis ähmis ei-tea-kuhu. Koju jõutakse tea millal. Tea(b), kas loomad said ikka korralikult sü̈̈a? Tea kas oli seeme halb või mis? Kaotas kindad kes teab kuhu. Teeks ei tea mis ära. Mõtleb enesest 
ei tea mis. Ei tea kedagi. Ei tea midagi. Tea, kumb astus esimese sammu, kuid .. (näited allikast EKSS 5: sub teadma); soome kukaties, kenties 'kes teab, võib-olla, ehk', ties 'mine tea, kes teab, taevas teab, tont teab; võta kinni; mine tea' (SES): Ties milloin tapaamme uudestaan 'Tea(b), millal jälle kokku saame', Saimme odottaa ties kuinka kauan 'Pidime tea(b) kui kaua ootama', Viivyn viikon, kenties kaksi 'Jään nädalaks, võib-olla kaheks', Kenties selitätte tarkemmin, mitä tarkoitatte 'Ehk selgitate täpsemini, mida silmas peate'.

Kirjeldatud ühendeis esineb teinekord sõna jumal: eesti Peab ennast jumal teab kelleks. Jumal seda teab, kus ta kolab. Jumal ise teab, mis sest saab; soome Kysyi kelloa herra ties monennenko kerran 'Küsis kella jumal teab mitmendat korda'. Sellelegi nähtusele leidub vaste läti keeles: diez / diezi / diezin 'mine tea' < dievs + zin 'jumal teab' (ME I: 487). Nagu ülalkirjeldatud nez, nii ka diez(in) esineb indefiniitsete pronoomenite, proadverbide jms koostisosana: diez kas 'tea kes / mis', diez $k \bar{a} d s$ 'tea(b) milline', diez kad 'tea(b) millal', diez cik 'tea(b) kui palju', diez vai 'vaevalt (küll)'.

\subsection{Läti keele mõju adpositsioonisüsteemile}

Läti keele mõju keelesaarte kaassõnafraasidele on märgatav. Läti keeles domineerivad indoeuroopa keeltele iseloomulikult eessõnafraasid. Läti kirja- ja ühiskeeles on õieti vaid kaks tagasõna - dēl 'tõttu, pärast' ja labad < laba dēl 'jaoks, pärast, heaks' - ning nende sagedus on väiksem kui eessõnadel (MLLVG I: 724), mistõttu on täiesti ootuspärane, et neid pole keelesaarte murretesse laenatud. Nii eesti kui ka läti keeles sõltub kaassõna pärast $=p \bar{e} c$ asendist kaassõnafraasi tähendus: pärast kontserti $=$ pēc koncerta (ajakaassõna), viisakuse pärast $=$ piekläjības pēc (põhjuskaassõna). Eesti keel eelistab eessõnadele tagasõnu, mis on iseloomulik soome-ugri keeltele: valdav osa eesti kaassõnadest on tagasõnad (EKG I: 37). Läti keelega piirnevates päriseesti murrakutes ja kolmandat põlve lätieestlaste keeles võib ka neutraalses kõnes täheldada läti keele eeskujul tavapäraste tagasõnade kasutamist eessõnadena: Krl kartulik_kasusõ $n u^{p}$ _pääle ${ }^{m} \_$maa kah - Miä ol'l, tuu ol'l õks all maa (VKM VI: 22); Balvi, Ida-Läti .. kes elas ligi piiri 'piiri ligidal', vrd lt pie robežas; sain pärast läbi panka kätte 'panga kaudu', vrd lt caur banku (Vaba 2010: 378). 
Leivu murrakus on juurdunud kaks läti keelest laenatud eessõna: bez ja pa. Suure kasutussagedusega on Leivus ilmaolekut väljendav eessõna bez / bes + abessiiv, vrd lt bez 'ilma' (Vaba 1997: 256): bez rõ 'ividó 'ilma riieteta' (Niilus 1937: 20), bes_kg $k^{i}$ 'erik_j'ezandada 'ilma kirikuõpetajata' (ibid.: 25), bez m 'aadõ 'ilma maata' (ibid.: 39), bez_l'iemadõ 'ilma lehmata' (ibid.: 39). Niiluse avaldatud Leivu tekstidest (1937) nähtub, et abessiiv väljendab ilmaolekut koos eessõnaga $b e z$, eesliiteta ühendeid leidub aniharva. Nagu läti keeles bez, nii ei esine ka Leivu murrakus bez / bes iseseisva määrsõnana. Olgu märgitud, et eessõna bäs 'ilma' kasutus on sage ka liivi keeles.

Läti eessõna $p a$ on laenatud tähendustes 'mingi osa, üksus või annus korraga; võrdsete üksustena pidevas järgnevuses': pa k'oud'ž' $i$ 'kuude kaupa', pa raazikste 'natukehaaval, vähehaaval, raasukeste kaupa', vrd It pa mēnešiem 'kuude kaupa', pa dal̦ām 'osade kaupa', pa vienam 'ühekaupa' (Vaba 1997: 327; MLLVG I: 746).

Leivu murrakus, hajusalt Lutsi murdes ja päriseesti murretes on genuiinsed adpositsioonid saanud läti keelele iseloomulikke tähendusi ja funktsioone.

\section{Omastav + tagasõna bäle (<pääle)}

Lei 'ollõw mü̈̈̈̈nüde .. l'emma kattõķümme r'ubl'i_bäle 'olevat müünud lehma kahekümne rubla eest' (Niilus 1937: 39), 'oš' $t$ ' $i$ ta ra'a_bäle r 'ät' $i$ 'ostis selle raha eest räti' (ibid.: 40); Hls saa_bäl 'kakjid 'saja katkutud [linapeo] eest' (VKM VII: 23),

vrd lt eessõna par + ak-instr 'üle, kõrgemal(e), peal(e), kohal(e), sealpool / sinnapoole ..; eest, vastu (osutab sellele, mille tasuks midagi makstakse või mille vastutasuks midagi toimub)' (ME III: 84-86 par; MLLVG I: 740-741).

\section{Eessõna üle + omastav}

1. ül' 'e kattõ n äd 'al'i 'kahe nädala pärast' (Niilus 1937: 32), ül'e âstagu 'aasta pärast' (ibid.: 39);

2. 'ül'e t'a tarkkuzõ 'tema tarkuse eest' (ibid.: 22);

3. ül'e r'ag 'aņide '[rahvajutt] nõidadest' (ibid.: 59);

4. Lut Määne sul um üle s'joo hädä! 'Mis häda sul sellest on!' (Nigol 1970: 67); 
5. t'u võ 'ttanu ruy',gi kä 'tte u 'n ül'nu ku a 'ndaw ül'e p ää 'too võtnud kaika kätte ja öelnud, et andvat vastu pead' (Niilus 1937: 57), vrd lt eessõna + ak-instr par:

1. 'pärast (põhisõnaga märgitud ajaühiku järel, möödudes)': par stundām trim 'tunni kolme pärast;

2. 'eest, vastu (osutab sellele, mille tasuks midagi makstakse või mille vastutasuks midagi toimub)': par sviestmaizi dabüja toreiz tās mājas 'võileiva [hinna] eest [ta] tookord need majad sai';

3. (kõnelemis-, mõtlemis- jms verbide rektsiooniline laiend, osutab sellele, kellest või millest räägitakse, mõeldakse)': par to nav vērts runāt 'sellest pole mõtet rääkida / sellest ei tasu rääkida';

4. 'tõttu, pärast (mingil põhjusel, millegi tõttu)': par kuo tad nu viņa nenāks 'mispärast ta siis nüüd ei tule', kas tev par daļu 'mis sul sellest / mis see sinu asi on';

5. (ühendites löömise kohta), vrd lt dot pa(r) galvu 'vastu pead andma', $p a(r)$ pieri sist 'vastu laupa lööma' (ME III: 84-86 par; MLLVG I: 740-741).

\section{Omastav + tagasõna bule / buló (<poole $)$}

ma sõida k"odõ_bulõ j'ema k'aõema 'ma sõidan koju ema vaatama' (Niilus 1937: 13), pieremîś'_ š' ei t reija bulõ 'peremees sõidab Riiga' (ibid.: 42), "o 'm min'nüde .. kuodõ_bulõ'on läinud .. koju' (ibid.: 45), zõ `s pakkõw je 'ttõ_bulõ 'siis [kurat] põgenevat kaugemale / ära' (ibid.: 44),

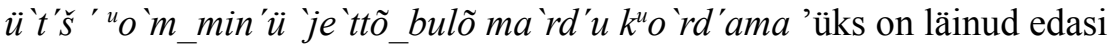
(= kaugemale) marju korjama' (ibid.: 51).

Tänapäeva läti keeles on vaid üks kohakääne, lokatiiv, mille abil väljendatakse nii asu- kui ka sihtkohta (MLLVG I: 405 jj). Ühemõttelise võimaluse väljendada sihtkohta pakub analüütiline alternatiiv, eessõnafraas $u z$ 'peale, poole' + ak-instr: uz Rīgu braukt 'Riiga sõitma' (ME IV: 311 jj $u z$; MLLVG I: 747). Leivu murraku tendents väljendada sihtkohta analüütiliselt on selgelt lätimõjuline. Kuid sihtkohta on Leivus väljendatud siiski ka illatiiviga (Niilus 1937: 26): tûl ta 'htu `s min'ä kalmõtta 'ida 'ta tahtis minna surnuaeda'. Esitatu taustal on huvipakkuv Keema ja Käsi tähelepanek, et Võru murdes eelistatakse kohakäändeis, eriti mitmuses, analüütilist väljendusviisi omastav + tagasõna, nt sõ 'r'mi pääle 'sõrmede peale, sõrmedele' (2002: 41). 
Kolmandat põlve lätieestlaste keeles võib läti mõjul siiski täheldada siht- ja asukohta väljendavate kohakäänete kattumist: [läks] Eestis 'Eestisse'. Samuti on läti keel teatud juhtudel suunanud sise- ja väliskohakäände valikut: jalutas .. laulu väljakuse 'lauluväljakule', vrd lt ienāca dziesmu svētku laukumā (lokatiiv); tuli seljal tassida', vrd lt uz muguras 'seljas = selja peal' (Vaba 2010: 378). Läti keeles pole võimalik lähtekohta väljendada käändevormidega, seda võimaldavad vaid eessõnafraasid. Kas ja mis määral kirjeldatud asjaolu on suurendanud läti keelest mõjutatud eesti murrete analüütilisust, vajab veel uurimist. Läti keeles pole teatavasti väliskohakäändeid, kuid praegune uurimisseis ei võimalda öelda, kuidas see asjaolu avaldub läti keelest tugevasti mõjutatud eesti murrete (k.a Leivu murraku) kohakäänete kasutamises. Kui väliskohakäändelised tagasõnad välja arvata, siis publitseeritud Leivu materjalides on väga harva väliskohakäändelisi vorme. Läti keele survel on liivi keeles väliskohakäänded paradigmakäänetena teatavasti praktiliselt hävinud.

\subsection{Lätilaenulised verbiprefiksid}

Prefiksatsioon on läti verbituletusele väga iseloomulik. On koguni verbe, mida ilma prefiksita ei kasutata või kasutatakse harva. Prefiksatsioon erineb sufiksatsioonist selle poolest, et prefiksverbe pole võimalik tuletada otse käändsõnadest: verbiprefiksid liituvad keeles juba eksisteerivate verbitüvede ette, ilma et põhjustaksid neis häälikumuutusi. Prefiksite leksikaalne tähendus, mis (osaliselt) säilib ka verbi koostises, on vaid neil prefiksitel, mis esinevad ka eessõnadena. Läti ühis- ja kirjakeeles võib verbitüve ette liituda mitu järjestikust prefiksit vaid üksikjuhtudel, tavaliselt siis, kui prefiksverbi ei tajuta enam morfoloogiliselt liitsena. Selliseid läti verbilaene pole teadaolevalt eesti keelest registreeritud. Läti keeles täidavad verbiprefiksid kolme põhilist funktsiooni: 1. näitavad orientatsiooni (suundumis-, paiknemis-, eemaldumis- ja kulgemiskohta), 2. perfektiivsust või 3 . annavad verbile uue semantilise tähenduse (vt lähemalt MLLVG I: 344 jj). Prefiksverbid on mitmetähenduslikud, nende konkreetne tähendus avaldub kontekstis. Läti prefiksverbidele on eesti keeles analoog ühendverbide näol. Läti verbiprefiksite kasutamise kohta genuiinsete verbide koostisosana on andmeid vaid Leivu murrakust. Sealt on teateid kuue läti verbiprefiksi kasutamise kohta: at-, iz-, no- [häälda: nuo-], pa-, pie- ja sa-. Liivi keeles on aga kasutusel kõik kümme läti ühis- 
ja kirjakeele verbiprefiksit, peale eespool loetletute ka aiz-, ap-, ie- ja pār-. Nimetatud kümnest prefiksist aiz 'taga / taha ..', no 'alla ..', pie 'juures / juurde, ääres / äärde, kõrval / kõrvale', ap 'ümber(ringi)', par 'üle, teis-, sealpool ..', pār 'üle, kohal', pa 'mööda, piki ..', uz 'peal / peale ..' ja peamiselt vanema kirja- ning murdekeele $i z$ 'välja(poole)' esinevad ka eessõnadena. Eessõnad, millest eesliited on kujunenud, on väga keerulise semantilise hargmikuga, sealjuures pole need harilikult kaotanud ka algset konkreetset kohatähendust. Leivu prefiksverbe iseloomustavad kõik ülalkirjeldatud, läti prefiksverbidele iseloomulikud tunnusjooned. Leivu murrakus on juurdunud järgmised verbiprefiksid: at-: at/laulatõd' $i$ 'lahutati', nt lass at/ma 'ssaga 'maksku tagasi, tasugu' (Vaba 1997: 251), vrd lt at- (väljendab eemaldamist või eemaldumist - eemale, lahti; lahkumist - ära; tagasitulemist - tagasi jne): at/laulāt 'abielu lahutama / scheiden (die Ehe)' (ME I: 172), at/maksāt 'tagasi maksma, tasuma, heastama; kätte maksma/ wiederbezahlen, vergelten, sich rächen' (ME I: 175); is-: is/pita' 'välja kannatada, taluda', is/tulema 'välja tulema, jätkuma' (Vaba 1997: 284), vrd lt iz- (osutab väljapoole liikumise suunda; väljendab tegevuse perfektiivsust; annab verbile uue semantilise sisu jne): iz/turēt 'taluma, välja kannatama, vastu pidama / aushalten, ertragen ..' (ME I: 821), $i z / n a \bar{k} t$ 'väljuma, välja tulema; teoks saama .. / herauskommen; hervorgehen, zustande kommen ..' (ME I: 775); nuu-: nuu/laskanu 'käest ära lasknud, laiale teele lasknud' (Vaba 1997: 325), vrd lt no-, murd nū- (väljendab liikumist ülalt alla; eemaldamist või eemaldumist - ära jne): nuo/ laidies 'allakäinud, kõlvatu, kombelõtv / liederlich, heruntergekommen' (ME II: 807); pa-: palaku 'lakkuda' (Vaba 1997: 327), vrd lt pa- (määratleb tegevuse kohatähenduse - mööda, piki, lahti; piiritleb tegevust aja, intensiivsuse ja täiusastme suhtes - veidi, pisut, natuke, väheke, mõnda või lühikest aega jne): pa/laizìt 'limpsima, pisut lakkuma / ein wenig lecken' (ME III: 56); pii- / pi-: p 'i/a 'nda' andeks anda', pii/d' 'uonu 'joobunud, purjus', pi/p 'aatamin '(kokku)rääkimine', a 'm $p$ 'ipit's 'itte 't 'on pigistatud, ahistatud' (Niilus 1937: 26), pi_eittanu 'ette heitnud, (jutule) vahele torganud' (Vaba 1997: 333-334), vrd lt pie-, murd pi- / pi- (osutab tegevuse kohta - juurde, juures, kokku; osutab ühendamisele või ühinemisele; väljendab tegevuse intensiivsust, perfektiivsust - täis; annab verbile uue semantilise sisu jne): pie/dzert 'terviseks jooma; end purju jooma / zu-, dazutrinken; sich betrinken' (ME III: 247), pie/runāt 'oma nõusse saama, veenma, keelitama / sprechend erreichen, bereden ..' (ibid.: 286), 
pie/spiest 'vastu, ligi suruma; tagant sundima / andrücken; (zu etw.) zwingen, antreiben' (ibid.: 294), pie/mest 'viskama, heitma; (kellelegi midagi) ette heitma, (midagi vahele) ütlema või torkama / zu-, hinzuwerfen; vorwerfen, in unangenehmer Weise an etwas erinnern ..' (ibid.: 271; EH II: 261), pie/dot 'juurde, pealekauba andma; andeks andma, andestama / zu-, hinzugeben; verzeihen, vergeben ..' (ME III: 247); sa-: sa/patama 'kokku rääkima' (Vaba 1997: 354), vrd lt $s a$ - (annab tähenduse - kokku; väljendab tegevust, millega on seotud palju tegijaid või mis on suunatud paljudele objektidele; väljendab tegevuse lõpetatust jne): sa/runāt 'kokku rääkima, kokku leppima / besprechen, bedingen' (ME III: 723).

Eraldi tuleb juhtida tähelepanu asjaolule, et päriseesti keelest pole üldse ja keelesaartelt on haruharva registreeritud prefiksverbilaene. Teada on vaid üksikud laenujuhtumid, kus lihtverbi kasutussagedus on väike: Lei atragõuma 'vastikuks muutuma' < 1t at/raugāties 'röhitama, röhitsema' (Vaba 1997: 251-252), patikama 'meeldima' < pa/tikt id. (ibid.: 331).

Leivu murrakule on iseloomulikud läti keele eeskujul tekkinud tõlkelised ühendverbid. Prevaleerivad afiksaaladverbiga välla moodustatud ühendverbid. Neil kõigil on otsevaste läti keeles: $n^{i} e \_\tilde{o m a v a \_e i t t u ̈ n u ̈ ~}$ vä 'lla 'need olevat ära kohkunud' (Niilus 1937: 31), vrd lt iz/bïties 'ehmuma, kohkuma, heituma, hirmuma, kartma lööma / erschrecken, in Furcht geraten'; iz/trūkties 'ehmuma, kohkuma, võpatama / erschrecken, zusammenfahren, auffahren'; iz/trūcināties 'ehmuma, kohkuma, kartma lööma, jahmuma / erschrecken, in Furcht geraten, sich entsetzen' (ME I: 717, 820); amma k'aonu vä 'llä' '[riided] on ära kadunud' (Niilus 1937: 14), k'aonu vä 'llä sõrmu 's 'kadunud ära sõrmus' (ibid.: 36), tuu_am k'aonu vällla 'too [= laps] on kadunud ära' (ibid.: 38), "om k'aonu välla 'on kadunud ära' (ibid.: 39), tî̀ 'ollõw k'aonu vä 'llä 'tee olevat kadunud ära' (ibid.: 61), vrd lt iz/zust '(ära) kaduma, kaotsi minema / verschwinden, vergehen' (ME I: 832); k'uuli vä 'lla 'suri ära' (Niilus 1937: 35), kuolõss vä'lla 'sureb ära'(ibid.: 31), j'ez 'a kûl'i vä lla 'isa suri ära' (ibid.: 63), vrd lt iz/mirt' / (ära) surema, välja surema / aussterben' (ME I: 772; EH I: 466); väigu pu ojakkõ "olnudõ ķül'mänü vä llä 'väike poeg olevat olnud ära külmanud' (Niilus 1937: 61), vrd lt iz/salt 'ära külmuma, surnuks külmuma, läbi külmuma / ausfrieren, erfrieren; durchfrieren, unter der Kälte leiden' (ME I: 795); la 'sk š'il'mä 'vä'lla 'tegi silmad lahti' (Niilus 1937: 11); la `skõva vä 'lla 'lasevad lahti [= vabaks]' (ibid.: 51), vrd lt iz/ laist 'välja, lahti laskma, vabastama' (LES); mu 'rd' d' ala vä llä (Niilus 
1937: 13) 'murdis jala', vrd lt iz/lauzt 'ära, välja, maha, lahti murdma'; "ollõw mõ 'skanu välla 'olevat pesnud puhtaks' (ibid.: 31), "om_mõskanu d'ala'vä 'lla 'on pesnud jalad puhtaks' (ibid.: 48), vrd lt iz/mazgāt 'puhtaks, välja, läbi pesema / auswaschen, ausspülen' (LES; ME I: 769); t̂ิ salva 's' l'i pu vä lla 'see hammustas saba (küljest) ära' (Niilus 1937: 46); zõ `s š 'ü'üb t'i emma vä 'lla' 'siis sööb tema [= rebase] ära' (ibid.: 52), vrd lt iz/êst 'ära sööma; läbi, katki sööma; söövitama / ausessen, ausfressen; ausätzen, ausbeizen' (ME I: 735); t'i' tapõttadõ vä lla 'teid tapetakse ära' (Niilus 1936: 109), vrd lt iz/kaut 'tapma, ära hävitama / ausrotten, vernichten ..' (ME I: 749); ollev välla unetanu 'olevat ära unustanud' (Niilus 1935: 378), om vä 'llä une unu 'on ära ununenud' (Nigol 1955: 140); tù o 'm s 'alanu vä 'llä 'too on salanud maha' (Niilus 1937: 39), vrd lt iz/liegties 'salgama, eitama / ableugnen' (EH I: 463); u'n_na väiku d'o 'uda' "o 'm v'arastanu vä'lla ķübara 'ja need väikesed kuradid on varastanud ära kübara' (Niilus 1937: 45), vrd lt iz/zagt'(ära) varastama / entwenden stehlen' (ME I: 831) jt.

Tegevuse perfektiivsust väljendav afiksaaladverb 'vällä on väga iseloomulik Hargla murrakule. Nähtus on täheldatav ka Rõuges. Näiteid: Har Siss 'pal'li пии' puu' vällä' 'siis põlesid need puud ära' (VKM VI: 29), vrd lt iz/degt 'ära põlema / ausbrennen' (ME I: 726), Siss sais' kõik' alalõ, nikagu vällä̈_ jahtu 'siis seisis kõik alal, niikaua kui ära jahtus' (VKM VI: 29), vrd 1t iz/dzist 'külmaks minema, ära jahtuma .. / kalt werden ..' (ME I: 732), Siss külveti vällä' 'siis külvati maha' (VKM VI: 29), vrd lt iz/sēt' '(maha) külvama / aussäen' (ME I: 796), sa'uputat Henu vällä' 'sa uputad Henu ära' (VKM VI: 30), Mõnikõrd 'tal'ssi 'mõisniku' orasõ vällä' 'mõnikord tallasid mõisnikud orase ära' (ibid.: 32), vrd lt iz/bradāt 'ära, maha, laiaks tallama / aus-, abtreten' (ME I: 718), Siss kuiusi hain vällä' 'siis kuivas hein ära' (VKM VI: 33), vrd lt iz/žūt '(ära)

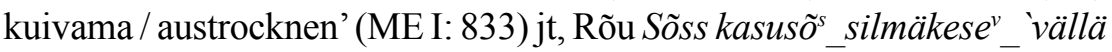
'siis kasvavad [kalamaimudele] silmakesed pähe' (VKM VI: 617), vrd lt iz/augt 'üles(poole) kasvama, tekkima; suureks kasvama / heraufwachsen, hervorgehen; aufwachsen' (ME I: 713) jt. Analoogilisi ühendverbe esitleb ka VES sub vällä: süübev .. vällä 'söövat .. ära', varastõdi .. vällä 'varastati ära', uppu vällä 'uppus ära', vrd lt iz/slīkt 'põhja vajuma, hukkuma, niiskuse tõttu riknema / im Wasser untergehen, vor Nässe ganz verderben' (EH I: 480-481). Levikut silmas pidades tuleb ka Hargla ja Rõuge murraku puhul arvestada eelkõige läti mõjuga, kusjuures enamasti leidub neile 
juhtudele läti keelest just $i z$-prefiksilis(t)e verbi(de) näol otsevaste, ehkki perfektiivsust on läti keeles võimalik väljendada muudegi verbiprefiksite abil, v.a prefiksiga $p \bar{a} r$ - (MLLVG I: 368). iz-prefiksverbide rohkus läti murdekeeles, eriti ülemläti murdes, aga ka mujal on seletatav asjaoluga, et $i z$ - korvatakse verbiprefiksiga $u z$ - või kasutatakse neid läbisegi (Endzelīns 1951: 659). Läti verbiprefiksi $i z$ - kasutust on samuti võinud rohkendada vene raz- / roz- 'katki, puruks; laiali; lahti ..' prefiksverbide eeskuju (ibid.: 658). Milliste läti verbiprefiksite kasutust ja kui ulatuslikult vene ja saksa keel on mõjutanud, pole süstemaatiliselt uuritud.

Ka eesti ühis- ja kirjakeeles väljendab afiksaaladverb välja perfektiivsust (EKG II: 21, 25), nt etendus on välja müüdud, jõudsin end korralikult välja puhata, haigus tuleb välja ravida, toit jagati välja, ohustatud liigid võivad välja surra (näited allikast EKSS 6: sub välja), kuid nende ühendverbide genees on teistsugune.

\subsection{Lätilaenulised partiklid ja adverbid Leivu murrakus ja Lutsi murdes}

Leivu murdekeelde on läti keelest kandunud sellised partiklid nagu jaau 'jaa, jah', vrd lt jau 'ju, juba, -p' (Vaba 1997: 284), nu 'tõesti, ju, noh', vrd lt $n u$ 'tõesti, tõepoolest, tõesti, ju, eks, no(h), säh' (Vaba 1997: 324): un_nu d'ouda 's tulõ va 'sta 'ja tõesti tuleb kurat vastu' (Niilus 1937: 25), a k nei, nu zõ `s "o ‘m 'aste! 'ah nii, noh siis on hästi' (ibid.: 64), ti ` , vrd It tik'nii, niivõrd, sedavõrd, muudkui, alles' (Vaba 1997: 381): ti $k$ vaj ag "obõst 'nii vaja hobust' (Nigol 1955: 150), vai, vrd lt vai 'kas, või'.

Leivu murrakusse on läti keelest suurel määral laenatud mitmesuguse semantikaga adverbe ja proadverbe (Vaba 1997: 469), nt do $k$ 'ometi, siiski', vrd lt dok(s), tok 'ometi, ju, siiski / doch, dennoch' (Vaba 1997: 272): tuu do 'käij_allõw tu 'ndanu .. 'too siiski ei olevat tundnud ..' (Niilus 1937: 55); gluše 'täiesti', vrd lt gluži 'täiesti, hoopis' (Vaba 1997: 279); partikkel kot' ' $^{\prime} / k^{u} o t^{\prime} s^{\prime}$ 'kas või; mis tahes', mis esineb rea adverbide

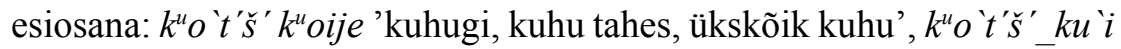
'ükskõik kuidas', $k^{u} o^{\prime} t^{\prime}$ 's $^{\prime}$ m 'üt 'ü 'ükskõik kuipalju' (vt Niilus 1940: 28 jj), vrd lt murd koč 'kas või' (Vaba 1997: 296); kruš' 's' $i$ 'äkki, kiiresti', vrd lt kruši id. (Vaba 1997: 300): ka 'rgaš' krušs's'i ül'e šs'illa 'kargas kiiresti üle silla' (Niilus 1937: 13); nu 'nüüd', vrd lt nu id. (Niilus 1940: 25; Vaba 1997: 324): un nuj 'ema i 'ķ’ja nüüd ema nuttis' (Niilus 1937: 19), lätteme 
nu ü 'tte paikka m 'ag 'ama 'läheme nüüd ühte [= samasse] kohta magama' (ibid.: 61), põrõda nuk_ka veid_dolla' 'nüüd võib ju ka olla ..' (ibid.: 59); l'aikam / laikkam 'võib-olla, vist', vrd lt laikam 'vist, arvatavasti, tõenäoliselt' (Vaba 1997: 307): na' in'emidze'min'n'ew le 'ina_mütten, l'aikam $t$ ' $a v$ ' $a z \tilde{o}$ 'need inimesed minevat linna mööda, võib-olla kohtavad [neid, keda otsivad]' (Niilus 1937: 16); miira 'rahul', vrd lt mierā id. (Vaba 1997: 317); muuž'igadõ 'väga, äärmiselt', vrd lt mūž̄̌gi id. (Vaba 1997: 320): kumbal "ollõw mûž'igadõ äste 'kellel olevat väga hästi' (Niilus 1937: 16); pagolam 'otsas, valmis, lõpnud, surnud', vrd ltg pag.olam id.; parvältt' $i$ 'asjata, ilmaaegu', vrd lt par velti 'tasuta, maksuta, jumalamuidu; asjata, ilmaaegu' (Vaba 1997: 330): $t^{\prime i}$ ema skuol'mi 'n "ollõw parvältti' tema koolitamine olevat asjata' (Niilus 1937: 34-35); pavi.ssam / pav.õssam 'täiesti, eriti, (mitte) sugugi', vrd lt pav.isam 'üldse, kõigest, ainult' (Vaba 1997: 332): ma vaiksikš'ti pavõssam ei v 'õt 'a 'ma vaikselt [= ilma teiste teadmata] sugugi ei võta' (Niilus 1937: 28), v'an 'a_jem 'a is_taija'l 'ät'i kīl ’t pavõssam 'vanaema ei osanud läti keelt üldse' (ibid.: 33); pilnigadõ 'küllalt, piisavalt, jätkuvalt', vrd lt pilnīgi 'täiesti, läbinisti, tervenisti, üleni' (Vaba 1997: 335); rikst'igadõ (< rikst'iga + dõ) 'tõepoolest, päriselt, õigesti, puhtalt', vrd lt riktīgi 'õigesti' (ibid.: 349): d'ää 's rikt 'igadõ san 't 'jääb tõepoolest vigaseks' (Niilus 1937: 32); sl'ikt 'i 'halvasti', vrd lt slikti id.: nâzõl "ollõw "olnudõ sl'ikt'i 'naisel olevat olnud halvasti' (ibid.: 30); tik 'nii, niivõrd', vrd lt tik id. (Vaba 1997: 381); tikai 'ainult, üksnes', vrd lt tikai 'ainult, üksnes, kõigest, alles' (ibid.: 381): a l'innu kûzlõ va 'rda' tikai sād'anu 'aga linakoonla varva ainult [olevat] saanud' (Niilus 1937: 10); vajag / vajak, Lut v 'aidzõ 'vaja, tarvis', vrd lt vajag, ltg vād'z' 'à 'vaja, tarvis' (Vaba 1997: 395): "olloww v'ajag min'na m 'ag 'ama 'olevat vaja minna magama' (Niilus 1937: 13).

Läti (latgali) algupära on nähtavasti Lut toor' $i$ / tuori / stuuri 'siis' (Voolaine 1976: 52-53): No toori i 'stõ nii kün'd 'no siis istus ja kündis', ? vrd lt tuobrīd, ltg tübreid id.

Lätitaustaliste tõlkeliste adverbide hulgas on nt d'umalk'ül 'küllalt = jumal + küll' (vt Nigol 1955: 150), vrd lt diezgan 'küllalt, piisavalt, parasjagu, omajagu, üsna', Lei je `nnõ_mun 'u 'endamisi, omaette': zõ `s ta nūr_jezand šüümnen d'uttõidzõ `s je 'nnõ_mun 'u 'siis see noorsand rääkis südames / sisimas endamisi' (Niilus 1937: 27), vrd lt pie sevis 'endamisi, omaette = enda juures'; ne 'i j jež $i$ 'niisama, niisamuti $=$ nii + ise', ta je'ež' $i$ id., vrd lt tāp.at id., tikp.at id. 'niisama, samuti, niisamuti, 
samamoodi': las_ta ķü ön'ig sāga ka nei_jeěz'i l'aimig ku š'in'a "ol õdõ 'las see kuningas saagu ka niisama õnnelikuks, kui sina oled' (ibid.: 17), nei_j 'eži t'ietta 's 'samuti / samamoodi tehakse' (ibid.: 59), u'n ta pu oi š' nei_jež'i t'enu 'ja see poiss samamoodi teinud' (ibid.: 59), se 'in_ i ěz'i 'siinsamas = siin + ise', vrd lt tep.at id. (ME IV: 165), ta 'n_j'ež' $i$ 'siinsamas, sealsamas = siin / seal + ise', vrd lt turp.at id. (ibid.: 272), nu j 'ežz' $i$ 'just praegu $=$ just + ise', vrd lt nup.at id. (ME II: 754), p 'õr õda j’ež' $i$ '(just) praegu = praegu + ise', vrd lt tagadìt pat id. (ME IV: 122 sub tagad; vt ka Niilus 1940: 23-26), ütten tükskün 'ühtejärge, lakkamatult = ühes + tükis', vrd lt vienā gabalā 'ühtesoodu, ühtevalu, ühtejärge, järjepanu, lakkamatult': ütten tükskün pi_eittanuj 'em ‘aló 'ühtesoodu ütelnud emale' (Niilus 1937: 32).

Leivus esinev kaasasolekut väljendav määrsõna ta 'ssa 'kaasa', tassan 'koos, ühes, kaasas' on samuti läti tõlkelaen, vrd lt līdzi (adverb) 'ühtlaselt, võrdselt, ühetasa (= ühel joonel, ühetasaselt); ühes, koos, kaasas, kaasa / gleich, eben; gerade so viel; zugleich, zusammen'; (eessõna) 'kuni' (ME II: 480-481): v' ${ }^{i}$ 't il 'uza s 'õbra ta `ssa 'võttis ilusa sõbra kaasa' (Niilus 1937: 13), min'ude j'ezaga ta `ssa 'läinud isaga kaasa' (ibid.: 38), vrd lt viņa ar prieku devusies têvam lìdzi zvejā 'ta läinud rõõmuga koos isaga kalale', ta v 'an'i $i k$ võtta ta 'ssa 'see vanik võta kaasa' (ibid.: 24), pierem 'iiš' võt ta 'ssa' 'peremees võtab kaasa' (ibid.: 42), ku nânõ ka_allõw tassan 'et naine ka olevat [s.o olgu] kaasas' (ibid.: 30), tü ‘tri 'k min'üde ta `ssa 'tüdruk läinud kaasa' (ibid.: 55).

Päriseesti murretes on registreeritud üsna ulatusliku lõunaeestilise levikuga lätilaenuline adverb apakaari 'ringiratast, tiirutades, ringe tehes' $<$ lt apkārt id. (Vaba 1997: 64).

Ülaltoodu pole kaugeltki ammendav. Olgu siiski juhitud tähelepanu sellele, et ehkki keelesaartel on adverbilaene palju, pole laenatud suure kasutussagedusega lokaaladverbe. Sealjuures ei ole läti keel märkimisväärselt kõigutanud ka kolmeaspektiliste kohaadverbide kasutust ning on säilitanud opositsiooni asukoha- ja sihikäänete kasutamisel, nt la ‘udu a l '(sauna)lava all' (Niilus 1937: 14), la 'udu ala 'saunalava alla' (ibid.: 14), ta $m$ ‘̈ekse_bäle 'selle mäekese peale'(ibid.: 52), ta m äekse bäl 'selle mäekse peal' (ibid.: 52). 


\subsection{Lätilaenulised konjunktsioonid}

Süntaktiliselt olulise sõnarühma moodustavad sidesõnad, mis seovad lause moodustajaid (EKG I: 40). Leivu murdest on registreeritud 5-6 laensidesõna, lisaks mitu hübriidvormi. Rinnastavatest sidesõnadest on läti keelest laenatud järgmised: 'aber / 'abõr / aaber 'aga', vrd lt aber (Vaba 1997: 249); bet / bät / bõt / abe `t (<a+bet) (Vaba 1997: 256), vrd It bet, murd boet 'aga, kuid, ent': zõs ma d'o taidze kor'd'ada raamadut, bõt k'ürüta k'ül is 'siis ma juba oskasin lugeda raamatut, aga kirjutada küll mitte' (Nigol 1970: 65); un / und / en / an 'ja', vrd lt un / und (Nigol 1955: 150; Vaba 1997: 392): $k^{u}$ on "om n'in'i' un aina' 'kus on lilled ja heinad' (Niilus 1937: 11); ? vai 'või, ehk', vrd lt vai 'või' (Vaba 1997: 395). Sidesõnad un ja bet kuuluvad läti keeles (kõneregistrist sõltumata) 10 kõige sagedama sõna hulka (http://www.liis.lv/latval/leksikologija/ leksokografija/biezumahtm).

Laenatud on ka alistav sidesõna $k u$ 'et': tū "ollõw tāš't $t$ 'inu, $k u$ tall "ollõw kõi $k$ äste 'too olevat jutustanud, et tal olevat kõik hästi' (Niilus

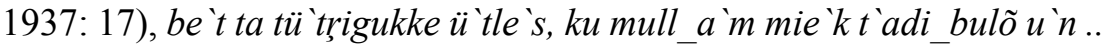
'aga see tüdrukuke ütleb, et ma pean minema tädi juurde ja ..' (ibid.: 27), vrd ltg $k u(<k \bar{u}<k u o)$ 'et / ka' (ME II: 297). Laenulist algupära on samuti ii .. ii 'nii(hästi) .. kui ka', vrd lt $i$.. i / ir .. ir id. (Vaba 1997: 283). Lutsis võib aga täheldada slaavi päritolu sidesõnade $a$ 'aga', $d a$ 'ja, aga', $k a b$ 'et' aktiivset kasutamist. Kõik loetletud sidesõnad esinevad ka latgali keeles.

Tõlkelaenulised võrdlussidesõnad võrdlustarindites on Lut ei / 'eigu (<ei + kui / ku), ü's 'kui (<is + kui), Lei ei'ku / eikku / e ku / isku / is 'kui, nagu', hübriidne nigu (<ne/ni + kui / ku) 'kui, nagu', vrd lt nik. 'a, nekā $i d$., ne (positiivses võrdluses), $k \bar{a}$ (negatiivses võrdluses). Näiteid: Lut tahra sitt vägeväp ü 's 'kui lauda sitt 'karjatara sõnnik on rammusam kui laudasõnnik' (Kallas 1894: 26), to ol'suuremb ei s'oo 'too oli suurem kui see', Lei $p$ 'ar 'õbadõ v 'ana in' 'emedze sõnna koulda' is ku tū sõnna soust $u$ `ssõ võ 'tta 'parem vana inimese sõna kuulda kui seda sõna suust välja võtta [s.o mitte kuulda võtta vanainimese nõuannet]', parebade küruta "om spulvaga is leistiguga 'parem on kirjutada sulega kui pliiatsiga' (Vaba 1997: 37, 42, 323). 


\subsection{Lätilaenulised interjektsioonid}

Neid on täheldatud nii keelesaartel kui ka läti-eesti kontaktvööndis kõneldud päriseesti murretes. Leivu murdest on registreeritud sellised lätilaenulised hüüdsõnad nagu $a{ }^{\prime} k$ 'ah' ( $a$ ' $k$ nei, nu zõ ` $s{ }^{u} O{ }^{\prime} m$ 'aste!' 'ah nii, noh siis on hästi' (Niilus 1937: 64)), eku 'ennäe, vaat', pii 'ptüi', Lutsist pas 's' 'ähvardussõna lastele' (< lt pas < pasargi 'hoia eest', vt Vaba 1997: 330), päriseesti murretest aks-tuu hüüdsõna inimeste ja loomade hurjutamiseks, hee ' 'vaata, näe', kunks 'imestust väljendav hüüatus' jt. Nii keelesaartelt kui ka Lätiga piirnevatest päriseesti murretest on registreeritud arvukalt lätipäraseid interjektsioone koduloomade kutsumiseks või peletamiseks (Vaba 1997: 467).

\section{Läti mõju sõnamoodustuses}

Läti prefiksite roll Leivu verbituletuses on tähelepanuväärne (vt ,5.12. Lätilaenulised verbiprefiksid”), kuid tagasihoidlik noomenituletuses. Keelesaartelt on registreeritud vaid üksikuid juhte, kus läti prefiks on liitunud genuiinse noomenitüve ette, nagu pa/jema 'võõrasema', vrd lt pa/māte id., pa/jeza 'võõrasisa', vrd lt pa/tēvs id. (Vaba 1997: 327), ning mõned läti eitusprefiksiga $n i$ - moodustatud Leivu pronoomenid ja adverbid (vt allpool). Suurem osa prefikstuletisi on läti keelest laenatud valmiskujul, nt Hää äprik, Lei a 'prik' paks üleleivaviil' < lt ap/rika id. (Vaba 1997: 247), Lei a 'prut's' 'kätis', vrd lt ap/ruoce id. (ibid.: 250), Lut apkeertam 'langetõbi', vrd lt ap/krist 'ümber või maha kukkuma, langema ..' (ibid.: 250), atlass 'võrse' < 1t at/lase id. (ibid.: 251), Har Trm Rõu atspuul' jt 'süstik' $<$ lt at/spuole id. (ibid.: 66), nuudukli' pl 'maksud (natuuras)', vrd lt nuo/ duoklis id. (ibid.: 325), Lei 'iirut'š' '(suur) nuga', vrd lt ie/ruocis 'tööriist, sõjariist' (ibid.: 283), Khk paalöuna 'õhtuoode', vrd lt pa/launags (ibid.: 146), Lei panašniga' 'mõrsjapoolsed sugulased pulmas'<1t pa/nācnieki id. (ibid.: 329), Har paargalina' jt, Lei $p^{u}$ orkkari 'heinakuhja- või viljarõugu malgad', vrd lt pār/kalas, pār/kari id. (ibid.: 145), Hää passakas 'tühi jutt, laimujutt', Lei påssak 'muinasjutt' < lt pa/saka id. (ibid.: 150).

Läti keelele on iseloomulik antonüümide regulaarne moodustamine eesliite ne-, murd na- abil (MLLVG I: 190), nt labs 'hea' - ne/labs 'halb, paha'; laikā 'sobival, õigel või parajal ajal' - ne/laikā 'ebasobival, ebasündsal ajal'; laime 'õnn' - ne/laime 'õnnetus, häda'; manāms 
'märgatav' - ne/manāms 'märkamatu'. Antonüümsuse väljendamine eitav-vastandava prefiksiga ai- / äi- 'ei, mitte, eba-' on iseloomulik keelesaartele: Lut ei/hüa 'kurat', vrd lt ne/labais 'paharet, vanatühi, vanakurat', ei/tark' rumal', Lei sgp a `i/v 'igast 'õnnelik, ilma hädadeta', äi_märgattaw 'ebaselge, arusaamatu' (lisanäited Vaba 1997: 43). Antonüüme tuletav läti eitusprefiks ne-, murd $n a$ - esineb keelesaartel läti laenudes, kuid ei liitu harilikult omatüvedega, nt Lei nalaim 'õnnetus' < 1t murd na/laime id. (Vaba 1997: 322). Läti eitusprefiksi ne-, murd ni- abil moodustatakse läti keeles ka eitavad asesõnad ja rida adverbe, samuti võrdlussidesõna $n e k \bar{a}$, murd nik. $\bar{a}$ 'kui, nagu': nekas 'ei miski, ei midagi', nekāds 'ei mingi, mitte ükski', nev.iens 'mitte ükski, mitte keegi' (MLLVG I: 539 jj), nek. ad 'mitte kunagi'. Lätilaenulise eitusprefiksiga $n i$ - moodustatakse ka Leivu eitav adverb nik.onagi 'mitte kunagi', vrd lt nek.ad, murd nik.ad id. (Vaba 1997: 324). Sellist võtet kasutab küll ka eesti ühis- ja kirjakeel (nt indefiniitsed pronoomenid ja substantiivid eikeegi 'mitte keegi, ei keegi; tähtsusetu, tundmatu, nimetu isik' ja eimiski 'mitte miski, ei miski; olematus, tühjus, miski olematu, mitteeksisteeriv või tühine'), kuid leksikaalsed antonüümid on keeleomasemad (EKG I: 549-551, 595; EKK: 638). Leivu lätilaenulise võrdlussidesõna nigu 'kui' kohta vt ,5.14. Lätilaenulised konjunktsioonid".

Läti (i)niek-liitelised isikuid ja vaid vähesel määral tarbeesemeid märkivad nimisõnad (MLLVG I: $143 \mathrm{jj}$ ) on eesti keeles muganenud nikliiteliste nimisõnadega, nende tüvevokaal on kas $-i$ või $-u$, kuid Leivu murrakus läti keele survel enamasti $-a$. Läti keeles on kõnealune liide produktiivne, mistõttu selle liitega läti laene on ka eesti murdekeeles arvukalt: Lut raamatnik 'õpetlane, tark mees', vrd lt grāmatnieks 'inimene, kes oskab lugeda ..', te `s'nik : tesnigi 'turukubjas' < ltg tis'n'īks 'kohtunik', Lei b 'iern'ik pl b 'iern'iga 'matuseline, peieline' < lt bērnieki pl id., liitsen'ik pl liitsen 'iga' 'tunnistaja' < lt liecenieks id., n 'ujõn'ik pl n'ujõn'iga' 'kontvõõras, lapuline' < lt nūjeniks id., panašniga' pl 'mõrsjapoolsed sugulased pulmas' < lt panācnieki pl id., zebenik 'torp, hobuse peakott' < lt zebenieks id., v'aalen 'ik : v 'aalen'iga 'vabadik, saunik'< lt val̦enieks id. jt (Vaba 1997: 311, 322, 324, 329, 375, 380, 395, 439-440), päriseesti pretsnik : pretsnigu jt 'kalade ülesostja' < lt precinieks 'kaubitseja, kaupmees', pussenigu pl 'lapulised' < 1t pušenieks 'pooleteramees; naaber' (Vaba 1997: 167-168, 172-173). Läti keelt on tartumurdelise lõunaeesti kirjakeele sufiksi -neck / -nek võimalikuks laenuallikaks 
pidanud Julius Mägiste (1962: 28) ja Ilse Kont (1974: 148). Suurem osa eesti ühis- ja murdekeele nik-liitelisi laene on siiski vene päritolu. Arvestatav on Helmi Neetari seisukoht, et nik-liite laenamist ja levikut on soodustanud genuiinne isikut märkiv ik-liide (1987: 46).

Läti noomeni- ja verbiliited esinevad küll laenudes, kuid ei liitu eesti omatüvedele. Morfoloogiliselt liitsete laenualuste hulgas tuleb tingimata nimetada $\bar{\imath} b$ - ja $u m$-liitega tuletatud (abstrakt)substantiive, nīca-liitelisi kohta märkivaid substantiive ja tāj-liitelisi tegijanimesid, nagu Lei meilestiiba 'armastus', vrd lt mīlest/îb/a id., võnnõstiba 'võit', vrd lt vinnest/ ìb/a id., leigum 'leping' < 1t lìg/um/s id., leikum 'käänak, kõvertee' < lt murd leik/um/s id., sl'i 'ktum 'halbus'< lt slik/um/s id., sl'i 'mnitsa 'haigla' $<$ lt slim/nīca id., (passaul'i) r'aad'itaiss '(maailma) looja' < lt rāà̄/tāj $/ s$ 'looja', pestitaiz 'lunastaja' < lt pestī/tāj/s id. (Vaba 1997: 309, 310, 316, 333, 347, 359, 399, 360).

Läti keel kasutab ohtralt deminutiive. Läti produktiivsemad vähendusliited on -ing- ja -itt-, oluliselt väiksema produktiivsusega on -ul-ja -el-jmt. Läti keele mõjuga võibki seletada Leivu deminutiivliiteliste nimisõnade rohkust. Läti deminutiivtuletiste vähendav, hellitlev vms tähendusvarjund on paljudel nn terminilaadsetel juhtudel neutraliseerunud (vt MLLVG I: 117, 131). Deminutiivne tähendusvarjund puudub nt sellisel laenul nagu Hls mutsin 'õllevaat' < lt muc/ing/a (Vaba 1997: 136). Leivu murrakus on läti deminutiivliide alati korvatud vastava omaliitega: 'adia/kõ 'kaheaastane lüpsilehm', vrd lt atdien/ît/e id. (Vaba 1997: 249), ii're/kse bàl(e) 'ahjumüüri peale', vrd lt iere, ier/iņ/šs 'ahjulõõr, ahjupink' (Vaba 1997: 283) jt. Deminutiivide rohkust Lutsi murdes mainib August Sang (1936: 406), kuid seal on vene, poola ja valgevene mõju enamasti siiski tõenäolisem kui latgali ja läti keele mõju. Järgmiste Lutsi deminutiivide puhul on läti (latgali) eeskuju siiski mõeldav, sest neile leiduvad lätist otsesed eeskujudlaenualused: kaari/keze' pl 'vanker' (Kallas 1894: 137), vrd lt rat/iņ/i pl 'käru, käsivanker', ratta/kõnõ 'vokk', vrd lt rat/iņ/š id. (Vaba 1997: 38), sõgla/kene, taeva sõgla/keze' pl 'Sõel (tähtkuju)' (Kallas 1894: 36), vrd It Siet/iņ/š id., tsyba/kõnõ 'tikutoos' (ibid.: 142), vrd lt sērkuoc/iņ/u cib/ iņ/a id. (Vaba 1997: 386). Needki deminutiivid on tähenduselt neutraalsed. Balti keeltele iseloomulik deminutiivliidete topeldus (vt MLLVG I: 118) pole laenudes täheldatav.

Läti laensõnade sõnalõppude ja liidete kohanemise või asendumise kohta eesti tuletusliidetega vt Vaba 1997: 437 jj. 


\subsection{Lõunaeesti taustaga kene-liitelised mikroetnonüümid, koha- ja perekonnanimed}

Deminutiivliidetel -iņ-, -itt-, -ul- ja -el-on eriline osa läti perekonnanimede kujunemisloos, kusjuures iņ-lõpulised nimed on väga suures ülekaalus. Läti deminutiivliitelised perekonnanimed on minetanud (algse) deminutiivse tähenduse. Läti mikroetnonüümides ja talunimedes esinev liiteelement -ing- lähtub tõenäoliselt aga ajaloolistest *inis-lõpulistest substantiveerunud adjektiividest, millel pole olnud ega ole deminutiivse ega subjektiivse hinnangu nüanssi (lähemalt Vaba 2002: 277, samas ka viited asjaomasele kirjandusele). Läti iņ-liitelised talunimed on sageli olnud vastavate perekonnanimede allikaks. in-lõppu sisaldavad talunimed ja muudki injärjendit sisaldavad toponüümid pole haruldased Lätiga piirneval alal Eesti poolel kogu etnilise ja riigipiiri ulatuses, aga ka kaugemal sisemaal.

Lõunaeesti taustaga kene-liitelised mikroetnonüümid (tüüp võrukene) ja kohanimed (tüüp Koobakene, Päevakese) järgivad ülalkirjeldatud tuletusmalli. Mägiste (1957: 219) on kene-liiteliste mikroetnonüümide kujunemisel oletanud võimalikku läti mõju. Nähtuse selgelt kagueestilist levikupilti silmas pidades tuleb laenuhüpoteesi pidada küllalt usutavaks. Hüpotees väärib tõsist tähelepanu ja aitab paremini tundma õppida KaguEesti etniliste protsesside ajalugu. kene-mikrotoponüümide probleemiga haakuvad (vähemalt osaliselt) ka Eesti perekonnanimistu kene- (tüüp Lõivokene), kese- (tüüp Poolakese) ja ke-liitelised (tüüp Lõiveke) nimed (lähemalt Vaba 2002: 278).

\subsection{Läti mõju morfoloogilis-süntaktilises ja süntaktilises tuletuses}

Leivu morfoloogilis-süntaktilises sõnatuletuses domineerib moodustusmall, kus liitnimisõna täiendosa (nimisõnafraasi laiend) on mitmuse omastavas. Mall on laenatud läti keelest, kus see on produktiivseim süntaktilis-morfoloogiline sõnamoodustusviis (MLLVG I: 200 jj). Näiteid: augidõ pou' 'okaspuud', meiladž'idõ tr 'uba 'mesilastaru', uipš'idõ aid 'õunapuuaed', vrd skuju koks / skuj/koks 'okaspuu', bišu koks 'mesipuu', ābeļu dārzs / ābel̦/dārzs 'õunapuuaed' (lisanäited Vaba 1997: 43). Leksikaalsete laenude hulgas on kirjeldatud struktuuriga otselaene: Lei tr 'eijukungu päiv 'kolmekuningapäev' < 1t treju kungu diena id. (Vaba 1997: 381). 
Läti keele eeskujul loodud süntaktilised tuletised on oleviku umbisikulised kesksõnad (harilikult püsivais sõnaühendeis), mis käibivad peamiselt koha, aja või tegevusvahendi tähenduses. Viimasel juhul märgivad ühendid tööriistu või nende osi, mitmesuguseid koduses majapidamises kasutatavaid riistu ja vahendeid jms. Päriseesti keelealal on seda tüüpi süntaktilisi tuletisi suhteliselt kitsal alal piki eesti-läti keelepiiri Häädemeestest Setuni, nt Hää murtav 'paindepakk, riist rattavitste ja reejalaste painutamiseks', altjoodav taar 'kurnaga tõrrest lastud jook', päältjoodav taar 'ülevalt nõust tasakesi, põhja settinud paksu pealt võetav jook', Krk suu 'mõstav siip 'silmapesuseep', rõ̃va mõstav siip 'pesuseep', oksa raiutev pakk 'pakk okste raiumiseks', põhupandav 'vahend põhu kandmiseks', Trv lehmänüssetav kipp 'lehmalüpsikibu', suitav 'sugemisvahend, linahari', Krl tsia tapõtõv tuut's 'seatapunuga', Har altlüüdäv ratas 'altvoolu-vesiratas', Rõu pähäk 'ääntävä 'sõnakuulmatu laps', Plv tõugatav uks 'lükanduks rehealusel (tagaküljel)', Se var'o 'kaetav 'peegel'. Samalaadseid tuletisi on registreeritud ka Lutsist, nt keritäv 'kerilaud', $p a$ 'a-nõstetava 'katlahark, -puu', pirrukistav väits 'peerunuga', pähäkääntävä väits 'liigendnuga', var'okaetav(a) 'peegel'. tav-kesksõna esinemine kirjeldatud funktsioonis on eriti iseloomulik Leivu murrakule: alates Heikki Ojansuust (käis leivude juures kogumisretkedel 1911 ja 1912) leidub näiteid kõigi uurijate sõnakogudes, kes murrakut kirja on pannud. Tegevusvahendit tähistavad nt 'aina riibutau re'a 'reha heina riisumiseks', 'ainan 'eidetav $m$ 'a '̌sin 'heinaniidumasin', gru 'hmõ r 'aotaw 'võsar, võsaraud e -vikat', mõ 'stav tõlu 'pesutõlv', pääsuittau k'emm 'peakamm', p 'uudaw' 'ese, mille külge saab midagi riputada'. Tegevuskohta märgib nt jeletaw kamõr' 'elutuba', tegevusaega 'uodõtawj 'ema 'rase (naine)'. Registreeritud näidete hulgas leidub vaid üksikuid, mis oma tähenduse poolest ei kuulu mainitud mõisterühmadesse, nt ülttäv sõna 'vanasõna, kõnekäänd'. tav-kesksõna esineb kirjeldatud funktsioonis kas nimi- või omadussõnana (sagedamini siiski omadussõnana), nt (nimisõnana) istutaw 'istumispaik', pi 'rdõ putontaw 'tulejalg, -hark', $p$ 'uudaw' ese, mille külge saab midagi riputada', pü 'ütäü 'lambihari' (sõna-sõnalt 'pühitav'); (omadussõnana) istutaw p'en ' $k$ ' 'istepink', kangutõtava vaaja' 'tõstepoomid kangaspuudel', pääsuittau k'emm 'kamm (pea sugemiseks)' jne (lisanäited Vaba 1997: 47-48).

Tänapäeva läti kirjakeelele on väga iseloomulik oleviku umbisikuliste kesksõnade atributiivne kasutamine püsiühendeis nimisõnadega, kusjuures täiendsõna suhe põhisõnaga on sihiline või määruslik (koha-, 
aja- või abinõumäärus) (vt MLLVG I: 646-648; Endzelīns 1951: 996 jj). Sellised püsiühendid märgivad mitmesuguseid argielunähtusi ja käibivad oskussõnadena, nt édamā karote 'supilusikas' (sõna-sõnalt 'söödav lusikas'), braucamais zirgs 'sõiduhobune' (sõna-sõnalt 'sõidetav hobune'), dzīvojamā māja 'elumaja' (sõna-sõnalt 'elatav maja'). Eriti produktiivne on oleviku umbisikuliste kesksõnade kasutamine tehnika oskussõnade tuletamisel märkimaks seadmeid ja masinaid, nt kartupeļu rokamā mašinna 'kartulivõtumasin' (sõna-sõnalt '.. võetav masin'), vêtījamā mašina 'tuulamismasin' (sõna-sõnalt 'tuulatav masin'), vērpjamā mašina 'ketrusmasin', kāršamā mašīna 'kraasimismasin'. Teatud juhtudel eelistatakse läti kirjakeeles atributiivsele sõnaühendile muid sõnamoodustusvõtteid (MLLVG I: 648). Ühe põhjusena mainitakse mitmeplaanilisi tähendussuhteid, mis eventuaalselt sugenevad täiend- ja põhisõna vahele. Transitiivsest verbist saadud kesksõna puhul võib nimisõna olla nii kesksõnaga väljendatud tegevuse objekt kui ka tegevuse sooritamise vahend, nt izzobojamās dziesmas 'pilkelaulud' (sõna-sõnalt 'pilgatavad laulud') võivad lätlase keeletajus olla nii 'laulud, mida pilgatakse' (objektisuhe) kui ka 'laulud, mille abil pilgatakse', seega siis 'pilkelaulud' (instrumentaal-adverbiaalne suhe). Arusaamatuste vältimiseks ja oskussõnadele esitatava selgusnõude tagamiseks kasutab läti keel siin muid sõnamoodustusvõtteid. Objektisuhte puhul (juhtum 'laulud, mida pilgatakse') ühendi tähendus ja sisevorm ehk sõnasõnaline tõlge kattuvad. Eestlane tajub nähtavasti kõiki käsitletavaid ühendeid, mille kesksõnalise komponendi aluseks on sihiline verb, objektisuhtes olevana. Seetõttu on nt lauldav laul eesti keeles normaalne ja vastuvõetav, lauldav masin aga mitte.

Keelesaarte sõnalaenude hulgas on mõned näited, kus laenualus on oleviku umbisikuline kesksõna, nt Lut apkeertam 'langetõbi', vrd lt krītams / krītamā kaite id. (sõna-sõnalt 'langetav tõbi').

Ka liivi keelele on kirjeldatud lätipärased tuletised iseloomulikud (vt Rudzīte 1976: 146-147).

\subsection{Tõlke- ja tähenduslaenud}

Need on keelesaarte, eriti Leivu murraku sõnaloome olulisi osi (vt lähemalt Vaba 1997: 38, 44). Tõlkelaene: $\ddot{u} t^{\prime} \breve{s}_{-}^{\prime}{ }^{i} e z ̌ z ' i$ 1. 'ainus, ainuke', vrd lt viens pats id., 2. 'mitte ükski (eitavas lauses)', vrd lt nev.iens pats id. (ME III: 124 sub pats). Tähenduslaene: Lei $k^{u} o^{~} r^{\prime}{ }^{\prime} d$ 'ama 'korjama', laenuline 
tähendus 'lugema', vrd lt lasīt 'korjama, võtma (nt kartuleid); lugema'; $j$ ' $e \check{z}$ ' $i$ 'ise', laenuline tähendus 'peremees': zõ 's tu j 'ež' $i$ ka_llõw tulnu ķü $n d m i z e s t k^{u}$ odõ_bulõ 'siis see peremees olevat ka tulnud kündmast koju'; Niilus 1937: 57 ekslikult 'tema ise', vrd lt pats 'abikaasa (mees), peremees, isand; ise / Gatte, Wirt, Herr; selbst' (ME III: 124; Endzelīns 1951: 540). Lisanäiteid vt Vaba 1997: 44.

7. Kokkuvõtvalt võib tõdeda, et läti keele mõju grammatikas ja sõnamoodustuses on ulatuslik Leivu murrakus ning märkimisväärne Lutsi murdes ja Lätiga piirnevates päriseesti murretes (Hargla, Karula, Rõuge).

\section{Kirjandus}

Alvre, Paul 1975. Über eine Neubildung in den finnisch-ugrischen Sprachen (auf dem Hintergrunde der pronominalen Typologie). - Sovetskoe Finnougrovedenie XI/4, 235-241.

Ariste, Paul 1962. Ühest keelekontakti juhust. - Keel ja Kirjandus 9, 550-556. Blokland, Rogier, Petar Kehayov 2010. Vene keele mõjust eesti keeles. Tagasivaateid ja perspektiive. - Keele rajad. Pühendusteos professor Helle Metslangi 60. sünnipäevaks. Paths of language. Festschrift for professor Helle Metslang on the occasion of her 60th birthday. (= Eesti ja soome-ugri keeleteaduse ajakiri. Journal of Estonian and Finno-Ugric Linguistics 1-2.) Tartu: ESUKA-JEFUL, 35-54.

Bušs, Ojārs 1999. Keel muutub ka Lätimaal. - Keel ja Kirjandus 8, 522-534.

EH I-II = Jānis Endzelīns, Edita Hauzenberga. Papildinājumi un labojumi K. Mülenbacha Latviešu valodas vārdnīcai. I, 1934. II, 1946. Rīgā: Kultūras fonda izdevums, Grāmatu apgāds.

EKG I = Mati Erelt, Reet Kasik, Helle Metslang, Henno Rajandi, Kristiina Ross, Henn Saari, Kaja Tael, Silvi Vare 1995. Eesti keele grammatika I. Morfoloogia. Sõnamoodustus. Trükki toimetanud Mati Erelt (peatoimetajana), Tiiu Erelt, Henn Saari, Ülle Viks. Tallinn: Eesti Teaduste Akadeemia Eesti Keele Instituut.

EKG II = Mati Erelt, Reet Kasik, Helle Metslang, Henno Rajandi, Kristiina Ross, Henn Saari, Kaja Tael, Silvi Vare 1993. Eesti keele grammatika II. Süntaks. Lisa: Kiri. Trükki toimetanud Mati Erelt (peatoimetajana), Tiiu Erelt, Henn Saari, Ülle Viks. Tallinn: Eesti Teaduste Akadeemia Keele ja Kirjanduse Instituut.

$\mathbf{E K K}=$ Mati Erelt, Tiiu Erelt, Kristiina Ross 2007. Eesti keele käsiraamat. Kolmas, täiendatud trükk. Tallinn: Eesti Keele Sihtasutus. 
EKSS = Eesti keele seletav sõnaraamat. 1-6, 2009. „Eesti kirjakeele seletussõnaraamatu" 2., täiendatud ja parandatud trükk. Toim. Margit Langemets, Mai Tiits, Tiia Valdre, Leidi Veskis, Ülle Viks, Piret Voll. Eesti Keele Instituut. Tallinn: Eesti Keele Sihtasutus.

Endzelīns, Jānis 1951. Latviešu valodas gramatika. Rīgā: Latvijas valsts izdevniecība.

Erelt, Mati, Matti Punttila 1999. Suomalais-ugrilaisten kielten reduplikaatiosta - Lähivertailuja 10. Suomalais-virolainen kontrastiivinen seminaari Tampereella 14. toukokuuta 1998. Toim. Lembit Vaba, Heikki Hurtta. (=Folia Fennistica \& Linguistica 23.) Tampereen yliopiston suomen kielen ja yleisen kielitieteen laitos. Tampere: Tampereen yliopisto, 3-12.

FBR $=$ Filologu biedrības raksti. Rīgā Latviešu Filologu biedrības izdevums.

Hornung, Johann 1693. Grammatica Esthonica, brevi, Perspicuâ tamen methodo ad Dialectum Revaliensem. Riga: Literis Joh. Georg Wilck.

Kallas, Oskar 1894. Lutsi maarahvas. Helsingi: Soome Kirjanduse Selts.

Kazlauskas, Jonas 1966. Lietuvių kalbos imperatyvo morfemos $-k(i)$ kilmè. Baltistica II, 69-72.

Kazlauskas, Jonas 1968. Lietuvių kalbos istorinè gramatika. Vilnius: Mintis.

Keem, Hella 1997. Võru keel. Eesti Teaduste Akadeemia Emakeele Selts, Võru Instituut. Tallinn: Eesti TA Emakeele Selts.

Keem, Hella, Inge Käsi 2002. Võru murde tekstid. (= Eesti murded VI.) Eesti Keele Instituut. Tallinn: [Eesti Keele Sihtasutus].

Kettunen, Lauri 1962. Eestin kielen äännehistoria. Kolmas painos. (= Suomalaisen Kirjallisuuden Seuran Toimituksia 156.) Helsinki: Suomalaisen Kirjallisuuden Seura.

Kont, Ilse 1974. Sufiks -nik eesti keeles. - Centum. Johannes Voldemar Veski 100. sünniaastapäeva tähistades. (= Emakeele Seltsi toimetised 9.) Tallinn: Valgus, 147-156.

Leikuma, Lidija 2003. Latgalīšu volūda 1. Intensīvā mācību kursa materiāli. Sanktpēterburgas Valsts universitāte. Vt ka Leikuma, Lidija. Latgalīšu volūda - gramatika; http://www.genling.nw.ru/baltist/Publicat/LatgVol1. $\operatorname{pdf}(25.12 .2010)$.

LES = Karl Aben 1966. Eesti-läti sõnaraamat. Tallinn: Valgus.

ME I-IV = K. Mülenbacha Latviešu valodas vārdnīca. K. Mühlenbachs Lettischdeutsches Wörterbuch. I-IV, 1923-1932. Rediǵējis, papildinājis, turpinājis Jānis Endzelīns. Rīgā: Izdevusi Izglīitíbas ministrija.

Metslang, Helle 1996. Evolutsioonilised ja revolutsioonilised uuendused grammatikas. - Congressus Octavus Internationalis Fenno-Ugristarum. Jyväskylä 10.-15.8.1995. Pars IV. Sessiones sectionum. Syntaxis et semantica \& Contactus linguistici et status hodiernus linguarum \& Cetera linguistica. Redegerunt Heikki Leskinen, Sándor Maticsàk, Tõnu Seilenthal. Jyväskylä: Moderatores, 87-92. 
Metslang, Helle 2010. Isepäine üldküsilause. - Emakeele Seltsi aastaraamat 55 (2009). Peatoimetaja Mati Erelt. Tallinn: Eesti Teaduste Akadeemia Kirjastus, 119-137.

MLLVG I = Mūsdienu latviešu literārās valodas gramatika I. 1959. Fonētika un morfolog̣ija. Rīgā: Latvijas PSR Zinātņu Akadēmijas izdevniecība.

Muižniece jt 1999 = Liena Muižniece, Helle Metslang, Karl Pajusalu. Eesti ja läti keele mineviku partitsiibi finiidistumine. - Keel ja Kirjandus 8, 522-534.

Must, Mari 1987. Kirderannikumurre. Häälikuline ja grammatiline ülevaade. Tallinn: Valgus.

Mägiste, Julius 1957. Rets. Uutta lätin kielen murteista. Kārlis Draviņš, Velta Rūkse. Laute und Nominalformen der Mundart von Stenden 1-2. (Slaviska institutionen vid Lunds universitet, Slaviska och baltiska studier 2-3.). Lund 1955, 1956. - Virittäjä, 218-220.

Mägiste, Julius 1962. Äldre ryska lånord i estniskan särskillt i det gamla estniska skriftspråket. (= Lunds Universitets Årsskrift N. F. Avd. I, Bd. 55, nr 1.) Lund: Gleerup.

Mägiste, Julius 1975. Eesti perekonnanimedest. - Finsk-ugriska småskrifter. Utgivna av seminariet för finsk-ugriska språk vid Lunds Universitet 3. Lund, 5-15.

Neetar, Helmi 1989. Laenamisest eesti sõnatuletuses. - Emakeele Seltsi aastaraamat 33 (1987). Keelest ja kultuuriloost. Tallinn: Eesti Raamat, $42-51$.

Nigol, Salme 1955. Märkmeid matkalt leivu keelesaarele. - Emakeele Seltsi aastaraamat I (1955). Tallinn: Eesti Riiklik Kirjastus, 147-151.

Nigol, Salme 1970. Paar sõna Leivu ja Lutsi murrakust. - Saaremaast Sajaanideni ja kaugemalegi. Tallinn: Valgus, 61-68.

Niilus, V[alter] 1935. Leivu rahvas. - Eesti Kirjandus 8, 365-381.

Niilus, V[alter] 1936. Leivu passiivist. - Eesti Keel 4, 109-112.

Niilus, V[alter] 1937. Valimik leivu murdetekste. Choix de textes dialectaux leivu. (= Akadeemilise Emakeele Seltsi toimetised XXXI. Äratrükk Õpetatud Eesti Seltsi Aastaraamatust 1936.) Tartu: Akadeemilise Emakeele Seltsi kirjastus.

N[iilu]s, V[alte]r 1938a. Alide Peterson +. - Eesti Keel 7/8, 254-255.

Niilus, Valter 1938b. Reduplikatiivsõnadest. - Eesti Keel 7/8, 224-232.

Niilus, Valter 1940. Mõningaid huvitavaid lätipärasusi leivu murdes. - Eesti Keel 1-2, 20-30.

Pajusalu, Karl 1989. Suhtlustaotlused inimkeelt muutmas. Tähelepanekuid eesti murrete verbimorfoloogiast. - Keel ja Kirjandus 3, 142-149.

Reķēna, Anton̦ina 1998. Kalupes izloksnes vārdnīca I-II. Rīga: Latviešu Valodas Institūts. 
Rosinas, Albertas 1982. Kai kurių deiktinių žodžių, intensifikatorių ir prieveiksmiu kilmès klausimu. On the origin of some deictic words, intensifying words and adverbs. Summary. - Baltistica XVIII/1, 39-46.

Rudzīte, Marta 1976. Rets: Eduard Vääri. Algupärased tuletussufiksid liivi keeles. Väitekiri filoloogiadoktori teadusliku kraadi taotlemiseks. Tartu 1974. - Sovetskoe Finno-ugrovedenie XII, 141-150.

Rūķe-Draviṇa, Velta 1961. Ns. lastenhoitajain kielestä. - Virittäjä, 85-91.

Rūkse-Draviņa, Velta 1977. Modification of speech addressed to young children in Latvian. - Talking to children: Language input and acquisition. Ed. C. Snow and C. A. Ferguson. Cambridge: Cambridge University Press, 237-254.

Rätsep, Huno 1989. Eesti keele tekkimise lugu. - Akadeemia 7, 1503-1524.

Saareste, Andrus 1955. Petit atlas des parlers Estoniens. Väike eesti murdeatlas. (= Skrifter utgivna av Kungl. Gustav Adolfs Akademien Nr 28.) Uppsala: Almqvist \& Wiksells.

Sang, Aug[ust] 1936. Lutsi maarahvas a. 1936. - Eesti Kirjandus 9, 399-409.

SC 1992 = Valik eesti kirjakeele vanemaid mälestisi a. 1524-1739. Välja andnud Albert Saareste ja Arno Rafael Cederberg. Faksiimileväljaanne. Tartu: Tartu Ülikool.

SES $=$ Soome-eesti suursõnaraamat. Suomi-viro-suursanakirja. 1-2, 2003. Toim. Valdek Pall. Koost. Anu Haak, Paul Kokla, Külli Kuusk, Helga Laanpere. Eesti Keele Instituut, Kotimaisten kielten tutkimuskeskus. TallinnHelsinki: Eesti Keele Sihtasutus, Kotimaisten kielten tutkimuskeskus.

Setälä, Eemil Nestor 1899. Yhteissuomalainen äännehistoria. I ja II vihko. Helsingissä: Suomalaisen Kirjallisuuden Seuran kirjapainossa.

Stolz, Thomas 1991. Sprachbund im Balticum? Estnisch und Lettisch im Zentrum einer sprachlichen Konvergenzlandschaft. Bochum: Universtitätsverlag Dr. N. Brockmeyer.

Zinkevičius, Zigmas 1980. Lietuvių kalbos istorinė gramatika I. Ivadas. Istorinė fonetika Daiktavardžių linksniavimas. Vilnius: Mokslas.

Zinkevičius, Zigmas 1981. Lietuvių kalbos istorinė gramatika II. Vilnius: Mokslas.

Zinkevičius, Zigmas 1982. Lietuvių kalbos postpoziciniai vietininkai. Postpositional locatives in Lithuanian. Summary. - Baltistica XVIII/1, 21-38.

Zinkevičius, Zigmas 1984. Lietuvių kalbos istorija I. Lietuvių kalbos kilmė. Vilnius: Mokslas.

Zinkevičius, Zigmas 1987. Lietuvių kalbos istorija II. Iki pirmujų raštų. Vilnius: Mokslas.

Tanning, Salme 2004. Karksi murrak. Toim. Karl Pajusalu. Eesti Keele Instituut. Tallinn: Eesti Keele Sihtasutus.

Toporov, Vladimir, Oleg Trubačev 1962. Lingvističeskij analiz gidronimov Verhnego Podneprov'ja. Moskva: Izdatel'stvo AN SSSR. 
Univere, Aili 1996. Idamurde tekstid. (= Eesti murded IV.) Tallinn: Eesti Teaduste Akadeemia Eesti Keele Instituut.

Vaba, Lembit 1990. Balti fragment eesti mesindussõnavaras? - Eesti keele ja kirjanduse kateedri töid I. Tallinn: E. Vilde nim. Tallinna Pedagoogiline Instituut, 35-45.

Vaba, Lembit 1991. Ferdinand Johann Wiedemann leivude uurijana. - Emakeele Seltsi aastaraamat 34 (1988). Sõna ja termin. Tallinn: Eesti Raamat, 74-85.

Vaba, Lembit 1992. Käblik on ahjulind! - Keel ja Kirjandus 8, 459-462.

Vaba, Lembit 1996. Über die Herkunft von est. keris. - Linguistica Uralica XXXII/1, 33-35.

Vaba, Lembit 1997. Uurimusi eesti-läti keelesuhetest. Tallinn-Tampere: Eesti Keele Instituut / Tampereen yliopiston suomen kielen ja yleisen kielitieteen laitos.

Vaba, Lembit 1999. Eesti-läti kakskeelsusest Valgas. Vaade ajalukku. - Keel ja Kirjandus 8, 535-541.

Vaba, Lembit 2002. Tähelepanekuid läti nimedest eesti perekonnanimistus. - Nime murre. Pühendusteos Valdek Palli 75. sünnipäevaks 30. juunil 2002. Koost. M. Kallasmaa. Toim. M. Kallasmaa, M. Langemets. (= EKI toimetised 11.) Tallinn: Eesti Keele Sihtasutus, 267-291.

Vaba, Lembit 2004. „Hellad nimed”. Ühest lätitaustalisest perekonnanimetüübist. - Emakeele Seltsi aastaraamat 49 (2003). Tallinn, 50-82.

Vaba, Lembit 2006. Läti keelest. - Eesti-läti vestmik. Igauņu-latviešu sarunvārdnīca. Tallinn: Ilo, 12-40.

Vaba, Lembit 2010. Eestlased ja eesti keel Lätis. Liepna ja Balvi Eesti siirdlaskonna tekke-, arengu- ja hääbumislugu ühe suguvõsa perepärimuste põhjal. - Eestlased ja eesti keel välismaal. Koost. ja toim. Kristiina Praakli, Jüri Viikberg. Tallinn: Eesti Keele Sihtasutus, 361-380.

VES = Võro-eesti synaraamat. Võru-eesti sõnaraamat. 2002. Koost. Sulev Iva. (= Võru Instituudi toimetised 12.) Tartu-Võru.

VKM VI = Kuiss vanal Võromaal eleti. 2005. Toim. Helju Kaal, Mari Must, Eevi Ross. (= Valimik korrespondentide murdetekste VI.) Eesti Teaduste Akadeemia Emakeele Selts. Tallinn: Emakeele Selts.

VKM VII = Ennemustitsel Mulgimaal. 2008. Toim. Helju Kaal, Mari Must, Eevi Ross. (= Valimik korrespondentide murdetekste VII.) Eesti Teaduste Akadeemia Emakeele Selts. Tallinn: Emakeele Selts.

Voolaine, Paulopriit 1976. Emakeele Seltis murdekogumise aoaegadelt. - Kodumurre 13. Toim. Heino Ahven. Eesti NSV Teaduste Akadeemia Emakeele Selts. Tallinn, 49-55. 


\title{
Lühendid
}

\author{
adess $=$ adessiiv \\ $\operatorname{adj}=$ adjektiiv \\ $\mathrm{adv}=\mathrm{adverb}$ \\ ains $=$ ainsus \\ ak-instr $=$ akusatiiv-instrumentaal \\ daat $=$ daativ \\ dem $=$ deminutiiv \\ $i d .=i d e m$ \\ ind $=$ indikatiiv \\ ltg = latgali murre \\ murd $=$ murdes \\ $\mathrm{p}=$ pööre; partitiiv
}

$\mathrm{pl}=$ pluural

plak $=$ pluurali akusatiiv

$\mathrm{plg}=$ pluurali genitiiv

pllok $=$ pluurali lokatiiv

$\mathrm{pp}=$ postpositsioon

prees $=$ preesens

refl $=$ refleksiiv

$\mathrm{sg}=$ singular

sgak $=$ singulari akusatiiv

$\operatorname{sgg}=$ singulari genitiiv

sglok $=$ singulari lokatiiv

$\operatorname{sgp}=$ singulari partitiiv 


\title{
Impact of Latvian-Estonian language contacts on the grammar and word-formation of Estonian dialects
}

\author{
Lembit Vaba
}

Latvian-Estonian and Estonian-Latvian contacts have had and increasingly have a trans-language character; they have occurred and occur through the prevalent intermediary languages. Both Estonian and Latvian have been heavily influenced by three contact languages: German, Russian, and English. For this reason, it is very difficult to establish the mutual morphological, syntactic, and semantic impact between Estonian and Latvian. The article deals with the development of the Estonian-Latvian linguistic boundary, the emergence of Estonian linguistic enclaves in Latvia, and the nature of Latvian-Estonian linguistic contacts.

The article highlights and analyses the following possible Latvian loans in the grammar of Estonian dialects: grammatical gender and manifestations of gender characteristics. They include plural nouns, Latvian-style expression of the superlative, Latvian impact on the formation of the moods (conditional, debitive, optative), reduplication of type finite verb of verb construction + action noun of the same verb, instances of Latvian-style verb government, the Latvian influence on the pronoun and adposition systems, Latvian verb prefixes, particles, adverbs, and pro-adverbs in the Leivu and Lutsi linguistic enclaves, borrowed conjunctions and interjections. The article analysis also the Latvian impact on word-formation.

Keywords: Finnic languages, Estonian, Baltic languages, Latvian, language contacts

Lembit Vaba

kieli-, käännös- ja kirjallisuustieteiden yksikkö

Kanslerinrinne 1

33014 Tampereen yliopisto

lembit.vaba@uta.fi 